\title{
The Entamoeba histolytica TBP and TRF1 transcription factors are GAAC-box binding proteins, which display differential gene expression under different stress stimuli and during the interaction with mammalian cells
}

Ravi Kumar Narayanasamy ${ }^{1}$, Carlos Alberto Castañón-Sanchez ${ }^{2,3}$, Juan Pedro Luna-Arias ${ }^{4 *}$ (D), Guillermina García-Rivera', Bartolo Avendaño-Borromeo ${ }^{4}$, María Luisa Labra-Barrios ${ }^{4}$, Jesús Valdés ${ }^{5}$, María Esther Herrera-Aguirre ${ }^{4}$ and Esther Orozco ${ }^{1}$

\begin{abstract}
Background: Entamoeba histolytica is the protozoan parasite responsible for human amebiasis. It causes up to 100,000 deaths worldwide each year. This parasite has two closely related basal transcription factors, the TATA-box binding protein (EhTBP) and the TBP-related factor 1 (EhTRF1). TBP binds to the canonical TATTTAAA-box, as well as to different TATA variants. TRF1 also binds to the TATTTAAA-box. However, their binding capacity to diverse core promoter elements, including the GAAC-element, and their role in gene regulation in this parasite remains unknown.

Methods: EMSA experiments were performed to determine the binding capacity of recombinant TBP and TRF1 to TATA variants, GAAC and GAAC-like boxes. For the functional analysis under different stress stimuli (e.g. growth curve, serum depletion, heat-shock, and UV-irradiation) and during the interaction with mammalian cells (erythrocytes, MDCK cell monolayers, and hepatocytes of hamsters), RT-qPCR, and gene knockdown were performed.

Results: Both transcription factors bound to the different TATA variants tested, as well as to the GAAC-boxes, suggesting that they are GAAC-box-binding proteins. The $K_{D}$ values determined for TBP and TRF1 for the different TATA variants and GAAC-box were in the range of $10^{-12} \mathrm{M}$ to $10^{-11} \mathrm{M}$. During the death phase of growth or in serum depletion, Ehtbp mRNA levels significantly increased, whereas the mRNA level of Ehtrf1 did not change under these conditions. Ehtrf1 gene expression was negatively regulated by UV-irradiation and heat-shock stress, with no changes in Ehtbp gene expression. Moreover, Ehtrf1 gene also showed a negative regulation during erythrophagocytosis, liver abscess formation, and a transient expression level increase at the initial phase of MDCK cell destruction. Finally, the Ehtbp gene knockdown displayed a drastic decrease in the efficiency of erythrophagocytosis in G3 trophozoites. (Continued on next page)
\end{abstract}

\footnotetext{
*Correspondence: jpluna@cell.cenvestav.mx; jpluna2003@gmail.com; jpluna@cinvestav.mx

${ }^{4}$ Departamento de Biología Celular, Centro de Investigación y de Estudios Avanzados del Instituto Politécnico Nacional (Cinvestav-IPN), Av. Instituto Politécnico Nacional 2508, Col. San Pedro Zacatenco, C.P, 07360 Ciudad de México, Mexico

Full list of author information is available at the end of the article
} 
(Continued from previous page)

Conclusions: To our knowledge, this study reveals that these basal transcription factors are able to bind multiple core promoter elements. However, their immediate change in gene expression level in response to different stimuli, as well as during the interaction with mammalian cells, and the diminishing of erythrophagocytosis by silencing the Ehtbp gene indicate the different physiological roles of these transcription factors in E. histolytica.

Keywords: Entamoeba histolytica, EhTBP, EhTRF1, GAAC-box mutation, Different stress stimuli, Gene knockdown, Differential gene expression

\section{Background}

Entamoeba histolytica is the causative agent of human amebiasis leading to 100,000 deaths per year [1]. The Entamoeba histolytica genome possesses 8201 protein-coding genes, including virulence genes and canonical transcription factors related to the basal transcription machinery $[2,3]$. The characterization of some gene promoters, such as those of the $h g l 5, f d x$, Ehpgp1, Ehpgp5 and actin genes [4-8] has allowed the identification of key elements in promoters, including the TATA-box (GTATTTAAAG/C), Inr (AAAAATTCA), GAAC (AATGAACT) and GAAClike (GAACTACAAA) core promoter elements, as well as other motifs, including the $\mathrm{H}_{2} \mathrm{O}_{2}$-regulatory motif (HRM) [9], URE-1 [10, 11], URE-3 [12], URE-4 [13], CCAAT-box [14], and CCCCCC motif [15]. The unusual core promoter element GAAC-box is described as a key player in driving the transcription start site of the $h g l 5$ gene promoter lacking both the TATA and Inr-boxes [4]. An in silico analysis of promoters for 246 genes showed that 43 genes contained the GAAC-box, 29 genes with the TATAbox, and 7 genes with both core elements [16]. In addition, it was found that $56 \%$ of 4000 genes contain the GAAC-like box [17]. Thus, the genome of this unicellular parasite is equipped with diverse promoter elements that coordinate transcriptional regulation. Several transcription factors have been identified and characterized in this parasite, including the TATA-box binding protein (EhTBP) [18, 19], EhEBP1, EhEBP2, EhHRM-BP, EhURE-BP, EhMyb, STAT, GATA, HSF [20], and the p53-like protein [21]. Recently, EhPC4 was identified as a key player affecting ploidy and genome stability in E. histolytica [22].

Multicellular organisms have evolved proteins related to the TATA-box binding protein (TBP) known as TBPrelated factors (TRFs) for specialized functions. TRF1 was first described in Drosophila melanogaster as involved in the regulation of specific gene subsets in the central nervous system and germ cells [23]. TRF2 has been broadly identified in metazoans, including Homo sapiens [24]. The deletion of TRF2 was lethal for embryos of Caernorhabditis elegans and D. melanogaster $[25,26]$. TRF2 selectively regulates TATA-less promoters by driving transcription of essential genes for chromosomal organization, as well as the PCNA and Tudor genes of Drosophila [26]. TRF3 is specific to vertebrates and is widely expressed in various human tissues and cell lines [27]. In the case of unicellular organisms, Crypthecodinium cohnii has a particular TBP, which is an intermediate class of transcription factor between TBP and TRFs [28], while Trypanosoma brucei has TRF4, which is divergent from metazoan TBPs and is considered as the universal regulator of transcription in this parasite because it is involved in transcription by the three RNA polymerases [29].

Entamoeba histolytica has two tbp genes, Ehtbp1 and Ehtbp2, which encode proteins of 234 and 212 amino acids, respectively. EhTBP2 is $100 \%$ identical to amino acids 23-234 of EhTBP1 and is endogenously silenced [18, 30, 31]. Entamoeba histolytica also contains a TBPrelated factor, named EhTRF1, which has a highly conserved C-terminal domain with $42.6 \%$ identity and $73.7 \%$ similarity to the full-length EhTBP. Like other members of the TBP family, both proteins possess a saddle-like structure [30]. EhTBP has the capacity to bind both the TATA-box and different TATA-box variants in vitro, with dissociation constants $\left(K_{D}\right)$ ranging between (1.04 $\pm 0.39) \times 10^{-11}$ and $(1.60 \pm 0.37) \times 10^{-10} \mathrm{M}$, which allowed us to propose the E. histolytica TATA-box sequence as $5^{\prime}-(1: \mathrm{T})(2: \mathrm{A})(3: \mathrm{T} / \mathrm{G})(4: \mathrm{T} / \mathrm{G} / \mathrm{A})(5: \mathrm{T} / \mathrm{G} / \mathrm{A})(6: \mathrm{A} / \mathrm{G})$ (7: A) (8: A)-3', where the numbers indicate the nucleotide position in TATA-box [19]. EhTRF1 has the ability to bind to the TATTTAAA-box as well, with a $K_{D}$ value of $(1.12 \pm 0.16) \times 10^{-11} \mathrm{M}$.

Determining the role of the closely related basal transcription factors TBP and TRF1 in the E. histolytica unicellular parasite will improve our understanding of the biology of this human parasite. As a first approach to unveiling the roles of these transcription factors, we determined the DNA-binding capacity of EhTBP and EhTRF1 for TATA variants, as well as for the GAAC core promoter element, through in vitro Electrophoretic Mobility Shift Assay (EMSA) experiments. Our results showed that both transcription factors have the capacity to bind to most of the TATA variants tested, but possess subtle differences in their $K_{D}$ values. Remarkably, they have the ability to bind to the GAAC-boxes as well. Furthermore, the differential expression profiles of the Ehtbp and Ehtrf1 genes were determined under different stress conditions, including serum depletion, heat-shock 
stress, and UV-irradiation. Additionally, we also determined their mRNA levels during the interaction of trophozoites with different mammalian cells, such as erythrocytes and Madin-Darby canine kidney (MDCK) target cells, as well as during the formation of amebic liver abscesses. Differential mRNA levels for both basal transcription factors were observed, suggesting that they have distinctive roles in these processes. Gene knockdown experiments in E. histolytica G3 trophozoites using the plasmid psAP-2 [32], unveiled the important role of Ehtbp in erythrophagocytosis.

\section{Methods}

\section{Entamoeba histolytica Cell culture}

Trophozoites of E. histolytica HM1:IMSS Clone A [33] were axenically cultured and maintained in either $15 \mathrm{ml}$ glass tubes (Kimax, Mexico) or $25 \mathrm{~cm}^{2}$ flasks (Corning, Corning, NY, USA) with $13 \mathrm{ml}$ or $20 \mathrm{ml}$ of TYI-S-33 Diamond's medium, respectively, at $37{ }^{\circ} \mathrm{C}$. For gene silencing experiments, E. histolytica G3 trophozoites were cultured with or without G418 (Sigma-Aldrich, Saint Louis, MO, USA) added to the TYI-S-33 medium [32].

\section{Expression and purification of recombinant EhTRF1 and EhTBP proteins}

Plasmids pEhtbp [19] and pcEhtrf1 [30] were transformed in Escherichia coli BL21(DE3)pLysS competent cells (Invitrogen, Carlsbad, CA, USA). Expression, purification and Western blot analysis of recombinant EhTBP (rEhTBP) and EhTRF1 (rEhTRF1) polypeptides were performed as described previously [30].

\section{Electrophoretic mobility shift assays and competition experiments}

Electrophoretic mobility shift assays (EMSAs) were performed using different amounts (10 to $500 \mathrm{nM}$ ) of each purified rEhTBP or rEhTRF1 polypeptides in reaction mixtures containing $1 \mu \mathrm{g} / \mu \mathrm{l}$ of poly $(\mathrm{dG}-\mathrm{dC}) \cdot \operatorname{poly}(\mathrm{dG}-\mathrm{dC})$ in binding buffer $(60 \mathrm{mM} \mathrm{KCl}, 1 \mathrm{mM}$ each dithiothreitol, EDTA, spermidine and $\mathrm{MgCl}_{2}, 10 \%$ glycerol, $12 \mathrm{mM}$ Hepes, $\mathrm{pH}$ 7.9). The double-stranded oligonucleotide to be used as a probe (TATTTAAA oligonucleotide, TATA variants or GAAC-boxes) was added to the reaction mixture $(20,000 \mathrm{cpm}, 557 \mathrm{pM}$ for each TATA-box, 64 pM for GAAC-box or 82 pM for GAAC-like box), which was previously labeled at its $5^{\prime}$-end with $\left[\gamma^{32} \mathrm{P}\right]$ ATP (3000 Ci/mmol, $10 \mu \mathrm{Ci} / \mu \mathrm{l}$, Perkin-Elmer, Waltham, MA, USA) with T4 polynucleotide kinase (Promega, WI, USA) and quantified with a Beckman LS-6500 liquid scintillation counter (Brea, CA, USA). EMSA assays were performed for $10 \mathrm{~min}$ at $4{ }^{\circ} \mathrm{C}$. For competition experiments, 200-fold molar excess of unlabeled TATTTAAA probe or the different TATA-box variants or GAAC-boxes (Table 1) were used as specific competitors, while an
Table 1 Sequences of the oligonucleotides used in EMSA experiments

\begin{tabular}{|c|c|}
\hline Oligonucleotide & Sequence $\left(5^{\prime}-3^{\prime}\right)$ \\
\hline TATTTAAA (1) & AATTCTCTATTTAAAGAGAATT \\
\hline TAgTgAAA (2) & AATTCTCTAgTgAAAGAGAATT \\
\hline TATTggAA (3) & AATTCTCTATTggAAGAGAATT \\
\hline TATTаAAA (4) & АATTCTCTATTaAAAGAGAATT \\
\hline TATgTAAA (5) & AATTCTCTATgTAAAGAGAATT \\
\hline gAgTTAAA (6) & AATTCTCgAgTTAAAGAGAATT \\
\hline TAcTcAAA (7) & AATTCTCTACTCAAAGAGAATT \\
\hline CACTCAAA (8) & AATTCTCCACTCAAAGAGAATT \\
\hline САсТTAAA (9) & AATTCTCCACTTAAAGAGAATT \\
\hline TATTTttt (10) & AATTCTCTATTTtttGAGAATT \\
\hline GAAC-box (Wild type) & AAGACAATGAACTAGAATG \\
\hline GAAC-box (Mutated) & AAGACCTACGATAAGAATG \\
\hline GAAC-like box ${ }^{b}$ & AGGCGAACTACAAAAGAT \\
\hline
\end{tabular}

${ }^{a}$ Wild type and mutated GAAC-boxes are identical to those reported for $\mathrm{hg} / 5$ gene [33]

${ }^{\mathrm{b}}$ This box was previously reported [17]

unspecific competitor [poly $(\mathrm{dG}-\mathrm{dC}) \cdot \operatorname{poly}(\mathrm{dG}-\mathrm{dC})$, poly(dI$\mathrm{dC})$ or $\left.(\mathrm{dA}-\mathrm{dT})_{18 \mathrm{mer}}\right]$ was used. In any case, selected competitors were added to reaction mixtures $10 \mathrm{~min}$ before the addition of labeled probes. When incubation time finished, all the reactions were electrophoresed on $6 \%$ nondenaturing polyacrylamide (PAGE) gels in $0.5 \times \mathrm{TBE}$ (45 mM Tris-borate, 1 mM EDTA, pH 8.3). Gels were then vacuum-dried, and DNA-protein complexes were detected in a PhosphorImager system (Bio-Rad, Hercules, CA, USA). All experiments were done at least three times in duplicate with reproducible results.

\section{Quantification of DNA-protein complexes}

The quantification of DNA-protein complexes formed by rEhTBP and rEhTRF1 with the DNA-probes was performed by densitometry analysis using the Quantity One software package version 4.6.2 (Bio-Rad). Normalization was performed with free probe to correct the total radioactivity loaded in each gel lane [19, 30].

\section{Determination of dissociation constants of DNA-protein complexes}

The $K_{D}$ values for rEhTBP and rEhTRF1 polypeptides for the different TATA-boxes, wild type and mutated GAAC-boxes were determined by EMSA as previously described [19, 30, 34]. The dissociation constant value calculation is briefly described (Additional file 1).

\section{Determination of the $E$. histolytica growth curve}

Two hundred thousand trophozoites from the midlogarithmic growth phase were inoculated in each of two-glass tubes containing $13 \mathrm{ml}$ of TYI-S-33 medium 
and incubated at $37{ }^{\circ} \mathrm{C}$ for $12,18,36,72,96$ and $120 \mathrm{~h}$. Then, cells were collected by centrifugation at $1800 \mathrm{rpm}$ $(652 \times g)$ in a $5810 \mathrm{R}$ centrifuge (Eppendorf, Hamburg, Germany) at $4{ }^{\circ} \mathrm{C}$. Cultured samples $(50 \mu \mathrm{l})$ were used to determine the viable cell number using $0.4 \%$ Trypan blue dye (Bio-Rad) in 1× PBS and a Neubauer chamber. The remaining cells were kept in an ice bath and immediately used for total RNA isolation as described below.

\section{Culture of trophozoites in serum depletion condition}

One million trophozoites collected at the exponential growth phase were cultured in $13 \mathrm{ml}$ of TYI-S-33 medium with or without $20 \%$ bovine serum at $37{ }^{\circ} \mathrm{C}$ for $12 \mathrm{~h}$ as described previously [35]. These trophozoites were then checked for viability and processed for total RNA isolation. To observe the cellular morphology, cells contained in $0.5 \mathrm{ml}$ of the culture were fixed with $2.5 \%$ $(v / v)$ glutaraldehyde in $1 \times$ PBS for 15 min at RT, washed three times with $1 \times$ PBS by centrifugation, and observed through a light microscope (Olympus BH-2, Tokyo, Japan). Photomicrographs were obtained using a Pixera Penguin 600CL digital camera (Pixera, Santa Clara, CA, USA) coupled to the light microscope.

\section{Confocal microscopy}

During the growth curve experiment, trophozoites were collected at each time point and washed with $1 \times$ PBS. Then, cells were grown on coverslips to be fixed with pre-warmed $4 \%$ paraformaldehyde (PFA) for $1 \mathrm{~h}$ at $37^{\circ} \mathrm{C}$ and permeabilized with $0.5 \%$ Triton X-100 for $10 \mathrm{~min}$ at RT. Cells were carefully washed with $1 \times$ PBS and blocked with $10 \%$ bovine serum for $30 \mathrm{~min}$ at RT. Cells were incubated overnight at $4{ }^{\circ} \mathrm{C}$ with the anti-EhTBP primary antibody (1:400), followed by incubation with goat anti-rabbit TRITC labeled (1:100) secondary antibody (Zymed, Waltham, MA) for $1 \mathrm{~h}$ at $37{ }^{\circ} \mathrm{C}$. The nucleus was stained with DAPI (Zymed) for $5 \mathrm{~min}$ at RT and the coverslips were carefully mounted with Vectashield antifading reagent (Vector Labs, Burlingame, CA, USA). The confocal image acquisition was performed using an LSM 700 microscope (Carl Zeiss, Oberkochen, Geremany). The captured images were analyzed and processed with the Zen 2009 lite edition software (Carl Zeiss). The same procedure was used for cells obtained in the presence or absence of serum for confocal microscopy analysis.

\section{Heat-shock of trophozoites at $42{ }^{\circ} \mathrm{C}$}

One million trophozoites collected at the mid-log phase were cultured at $37^{\circ} \mathrm{C}$ or $42{ }^{\circ} \mathrm{C}$ in $15 \mathrm{ml}$ glass tubes containing $13 \mathrm{ml}$ of complete TYI-S-33 medium for $4 \mathrm{~h}$ [36]. A sample of $0.5 \mathrm{ml}$ was separated before the RNA isolation for the examination of the cellular morphology as described above, and total RNA extraction was carried out immediately and stored at $-80{ }^{\circ} \mathrm{C}$ until use. As a control indicator of heat-shock stress, the gene expression level of Ehhsp70 was measured by RT-qPCR [36].

\section{Exposure of trophozoites to UV irradiation}

Two million trophozoites harvested at exponential growth phase were transferred to Petri dishes $(100 \mathrm{~mm}$ in diameter). Following their adherence to the surface of the petri dish, the culture medium was removed and the cells were immediately exposed to $254 \mathrm{~nm}$ UV light $\left(150 \mathrm{~J} / \mathrm{m}^{2}\right)$ for eight seconds as described [37] using a Stratalinker 1800 (Stratagene, San Diego, CA, USA). After exposure, $20 \mathrm{ml}$ TYI-S-33 medium prewarmed at $37{ }^{\circ} \mathrm{C}$ was added to the plates. The cells were detached by placing them on the ice after 5,15 and $30 \mathrm{~min}$. The cells were processed later for the viable cell count and total RNA isolation. Cells unexposed to UV irradiation were used as a control. The Ehblm, Ehrad54 and Ehpcna DNA repair genes were included in this experiment as reference genes [38, 39].

\section{Erythrophagocytosis}

Fresh human erythrocytes ( $\mathrm{O}$ type $\mathrm{Rh}$ negative) were washed three times with sterile filtered $1 \times$ Alsever isotonic solution $(0.42 \% \mathrm{NaCl}, 0.8 \%$ sodium citrate, $0.055 \%$ citric acid and $2 \%$ D-glucose) and incubated with trophozoites (50:1 erythrocytes/trophozoites ratio) in serum free TYI-S-33 medium at $37{ }^{\circ} \mathrm{C}$ for $2,5,10,15$ and $30 \mathrm{~min}$ [33]. After incubation, cold distilled water was added to burst the non-ingested erythrocytes and trophozoites were collected for total RNA isolation and counting of ingested erythrocytes by staining cells with 8.4 $\mathrm{mM}$ diaminobenzidine. For counting, a population of 100 trophozoites was selected randomly for all time points. Images were obtained as mentioned before.

\section{MDCK cell monolayer destruction by trophozoites}

Initially, MDCK epithelial cells were cultured in DMEM medium supplemented with penicillin (100 I.U./ml; in vitro), streptomycin $(100 \mathrm{mg} / \mathrm{ml}$, in vitro), $10 \%$ fetal bovine serum (Gibco, Carlsbad, CA, USA) and insulin $\left(0.08 \mathrm{U} / \mathrm{ml}\right.$, Eli Lilly, Indianapolis, IN, USA) at $37^{\circ} \mathrm{C}$ and $5 \% \mathrm{CO}_{2}$. One and a half million trophozoites were carefully deposited on a confluent fresh MDCK epithelial cell monolayer and incubated at $37^{\circ} \mathrm{C}$ in serum free TYI-S-33 medium for 5, 15 and $30 \mathrm{~min}$. After incubation, trophozoites were detached by repetitive washing with ice-cold $1 \times$ PBS and collected for total RNA extraction. For the evaluation of MDCK cell destruction by trophozoites, cells were fixed with $2.5 \%$ glutaraldehyde in $1 \times$ PBS for $15 \mathrm{~min}$ at RT and washed with $1 \times$ PBS as previously described [40]. Cells were then stained with $1 \%$ methylene blue in $0.01 \%$ sodium borate buffer $(0.2 \mathrm{M}$ boric acid and $0.05 \mathrm{M}$ sodium tetraborate, $\mathrm{pH} 8.7$ ) for $10 \mathrm{~min}$ at $\mathrm{RT}$ and 
compared with intact MDCK cell monolayer. Finally, stained monolayers were washed three times with $1 \times$ PBS and left to air dry the plate to capture images using the Epson V500 Photo scanner. The percentage of monolayer destruction was measured using ImageJ software.

\section{Generation of amoebic hepatic liver abscesses in hamsters}

To induce the formation of liver abscesses, Syrian gold hamsters (Mesocricetus auratus) were anesthetized using $45 \mathrm{mg} / \mathrm{kg}$ of sodium pentobarbital, and intraportally injected with four million trophozoites collected from the mid-log phase. After seven days of post-inoculation, animals were sacrificed by giving an overdose of sodium pentobarbital following the guidelines of the 2000 AVMA Panel of Euthanasia. Livers were dissected under sterile conditions for examination of abscesses. The abscesses were cut into small pieces to facilitate the release of virulent trophozoites into $13 \mathrm{ml}$ pre-warmed TYI-S33 medium as described [41]. Once the cultures were confluent, cells were harvested for total RNA isolation. Three hamsters were used for each experiment and three independent experiments were performed. Animal management was supervised by a licensed veterinarian in accordance with the principles set forth in the $\mathrm{NIH}$ guide for the care and use of laboratory animals. These experiments were approved by the Institutional Animal Care and Use Committee (IACUC/Bioethics) of Cinvestav-IPN.

\section{Gene silencing using $E$. histolytica G3 trophozoites}

A fragment of $400 \mathrm{bp}$ from the translation start codon (ATG) of Ehtbp gene was amplified using specific primers (Additional file 2: Table S1) and cloned into a pJET1.2 vector (Thermo Scientific, Waltham, MA, USA). DNA recognition sites for StuI and SacI at 5' - and 3'-ends, respectively, were included for cloning this fragment into the psAP2 vector [32]. G3 trophozoites were cultured in 6 -well plates (Corning) and $20 \mu \mathrm{g}$ of the plasmid psAP2Ehtbp were transfected using Superfect liposomes (Qiagen, North Rhine-Westphalia, Hilden, Germany). After $48 \mathrm{~h}$ of transfection, $1 \mu \mathrm{g} / \mathrm{ml}$ of G418 (Sigma-Aldrich) was added and gradually increased up to $10 \mu \mathrm{g} / \mathrm{ml}$ to obtain stable transfectants. As a control, the empty vector was transfected and stable transfectants were obtained. To measure the rate of erythrophagocytosis and to obtain growth curve, we followed the procedure as described above.

\section{Quantitative real-time PCR (RT-qPCR)}

Total RNA isolation was performed with Trizol reagent (Invitrogen) following the manufacturer's instructions and quantified with a Nanodrop system 2000c (Thermo Scientific). Total RNA $(5 \mu \mathrm{g})$ was DNase I-treated (Thermo Scientific) and samples of $100 \mathrm{ng}$ were subjected to cDNA synthesis at $50{ }^{\circ} \mathrm{C}$ for $30 \mathrm{~min}$ and specific genes were amplified by PCR using the SYBR FAST One-Step RT-qPCR (Kapa Biosystems, Wilmington, MA, USA) under the following conditions: initial denaturation at $95{ }^{\circ} \mathrm{C}$ for $5 \mathrm{~min}$, followed by 40 cycles of denaturation at $95^{\circ} \mathrm{C}$ for $10 \mathrm{~s}$, annealing at $58{ }^{\circ} \mathrm{C}$ for $30 \mathrm{~s}$ and extension at $72{ }^{\circ} \mathrm{C}$ for $20 \mathrm{~s}$ using an $\mathrm{Eco}^{\mathrm{Tm}}$ Real-Time PCR System (Illumina, San Diego, CA, USA). The expression level of target genes was normalized with the house keeping Eh40Ss2 gene (GenBank: EHI_020280), and then the relative gene expression was measured using the equation $2^{-\Delta \Delta C q}$ [42] with the Eco Real-Time PCR System software version 4.02. Appropriate no added reverse transcriptase and non-template controls were included in each of 48-well reaction plates. The oligonucleotides used in RT-qPCR assays are listed (Additional file 2: Table S1). For all statistical analysis, the Graphpad Prism version 6.0 program was used. The analysis was performed using two tailed unpaired Student's ttest and significant difference values were shown as mean \pm standard deviation of three biological replicates, each done in triplicate.

\section{Results \\ EhTBP and EhTRF1 have the capacity to bind to different TATA-variants in vitro}

We previously described the DNA-binding capacity of rEhTBP for different TATA variants, as well as the binding capacity of rEhTRF1 for the TATTTAAA-box [19, 30]. To continue with the characterization of these transcription factors (rEhTBP and rEhTRF1), they were expressed in $E$. coli (Fig. 1a, lanes 4 and 7, respectively) and purified by Immobilized Metal Affinity Chromatography (IMAC) (Fig. 1a, lanes 5 and 8, respectively). Western blot analysis confirmed that they are his-tagged proteins (Fig. 1b). To determine whether they were biologically active, they were analyzed in EMSA assays using the TATTTAAA-box as a probe [43]. Recombinant EhTRF1 and EhTBP proteins showed TATTTAAA-box binding capacity (Fig. 1c, lanes 2 and 6, respectively). Complexes formed by these two proteins were specific as their formation was completely abolished by 200 -fold molar excess of unlabeled probe (Fig. 1c, lanes 3 and 7), but remained intact when an excess of unspecific competitor was used (Fig. 1c, lanes 4 and 8). Then, EMSA assays were performed using different TATA variants that have not been previously studied (Fig. 1d-h). Assays performed with the TAgTgAAA(2) variant showed a slightly higher amount of DNA-protein complexes formed by rEhTRF1 as compared to rEhTBP (Fig. 1d, lanes 2 and 7, respectively). A similar behavior was observed for TATgTAAA(5) (Fig. 1e, lanes 2 and 7, respectively), and gAgTTAAA(6) (Fig. 1f, lanes 2 and 7). The formation of DNA-protein complexes was abolished when a 200-fold molar excess of unlabeled specific TATA variant was used in competition experiments for both 
a
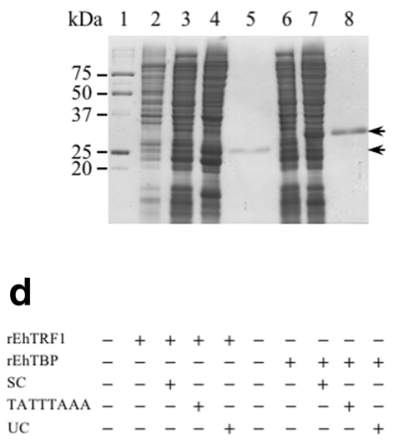

g

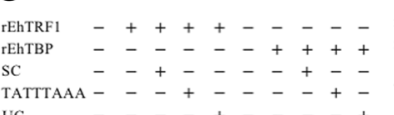

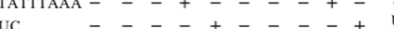

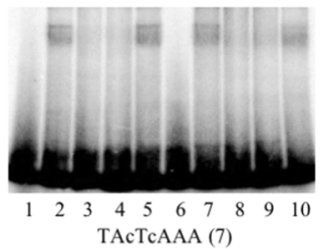

b

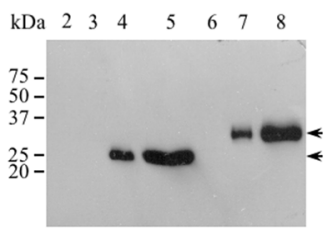

e

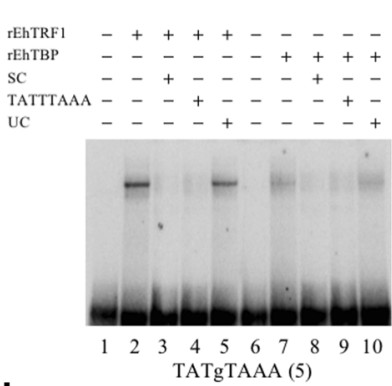

h
C

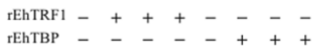

$\mathrm{SC} \quad-\quad+---+$

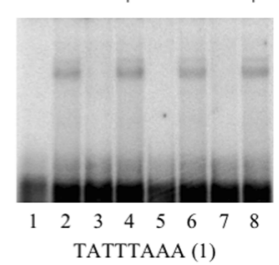

f

TATTTAAA (1)

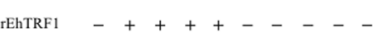

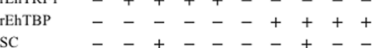

$-2+--5+-5$

UC $--\ldots+--\ldots+$
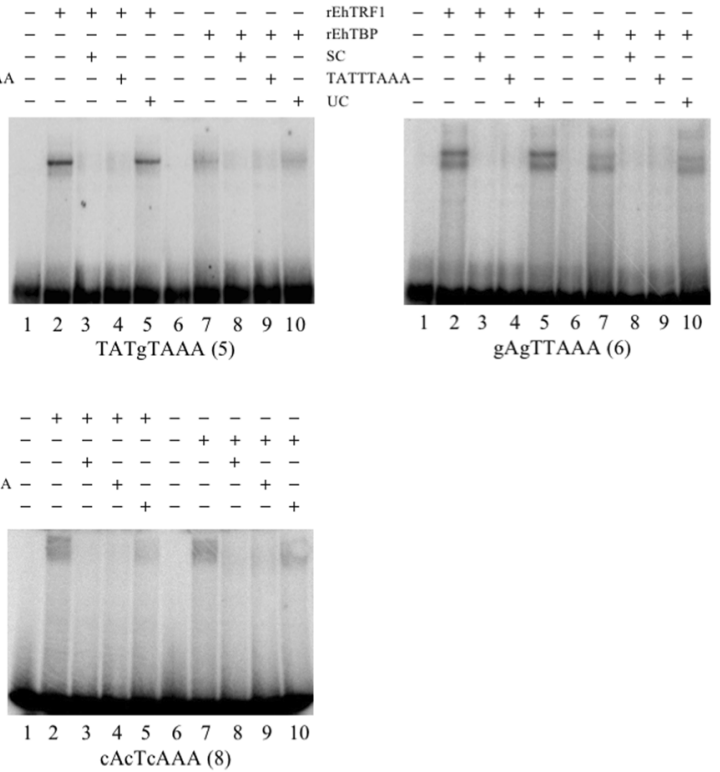

Fig. 1 EhTBP and EhTRF1 have DNA-binding activity to different TATA variants in vitro. Recombinant EhTBP and EhTRF1 were expressed in E. coli BL21(DE3) pLysS, purified by IMAC and analyzed by electrophoresis as described in Methods. a SDS-PAGE (12\%) gel analysis of extracts from bacteria transformed with pRSET A (Lane 2), pcEhtrf1 (Lanes 3 and 4), pEhtbp (Lanes 6 and 7). Protein expression was induced with 1 mM IPTG for rEhTRF1 and rEhTBP (Lanes 4, and 7, respectively). rEhTRF1 and rEhTBP purified proteins (arrows) are shown in Lanes 5 and 8, respectively. b Western blot of the gel shown in a using anti-His tag monoclonal antibodies. EMSA assay to determine the DNA-binding activity of purified rEhTRF1 and rEhTBP using different probes: (c) TATTTAAA(1); (d) TAgTgAAA(2); (e) TATgTAAA(5); (f) gAgTTAAA(6); (g) TAcTcAAA(7); (h) cAcTcAAA(8). Abbreviations: UC, unspecific competitor; SC, specific competitor

rEhTRF1 and rEhTBP polypeptides (Fig. 1d-h, lanes 3 and 8 , respectively). The specific competition was obtained when the TATTTAAA-box was used as a competitor for the different TATA variants tested (Fig. 1d-h, lanes 4 and 9). When a 200-fold molar excess of unspecific competitor was used in competition experiments, the formation of DNA-protein complexes was unaffected (Fig. 1d-h, lanes 5 and 10). The formation of DNAprotein complex for cAcTTAAA (9) was seen only with rEhTRF1 (Additional file 3: Figure S1).

\section{EhTBP and EhTRF1 are able to bind the GAAC-boxes in vitro}

To test the possibility that EhTRF1 and EhTBP are two putative GAAC-box binding proteins (GBPs), the DNAbinding capacities of these two proteins were determined by EMSA experiments (Fig. 2a, lanes 2 and 7, respectively).
The complexes formed by these transcription factors with the GAAC-box were specific as they disappeared with 200fold molar excess of unlabeled GAAC-box (Fig. 2a, lanes 3 and 8). The formation of these DNA-protein complexes was also competed with a 200-fold molar excess of the TATTTAAA-box (Fig. 2a, lanes 4 and 9). In addition, the binding capacity of rEhTBP and rEhTRF1 for the GAAClike box was also tested. The former bound the GAAC-like box, but the complex was barely competed by the specific competitor (Fig. 2b, lanes 2 and 3, respectively) and was not abolished with either 200-fold molar excess of poly(dI$\mathrm{dC}$ ) or (dA-dT) 18 mer (Fig. 2b, lanes 4 and 5, respectively). The latter formed a complex with the GAAC-like box, which was specifically competed (Fig. 2b, lanes 6-9). Moreover, the formation of the GAAC-rEhTBP or GAACrEhTRF1 complexes was not abolished when a 200-fold molar excess of the mutated GAAC-box was used (Fig. 2c, 

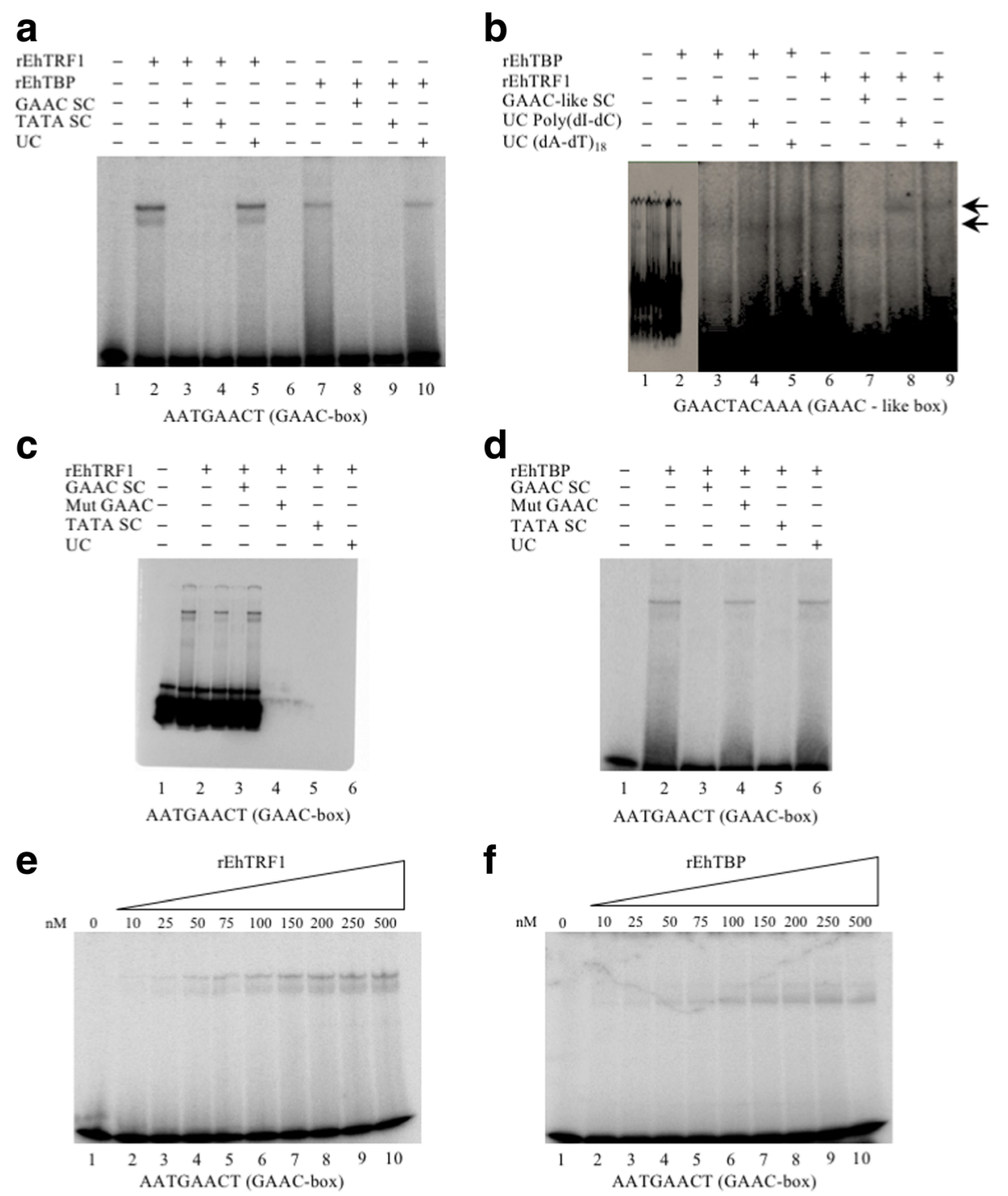

Fig. 2 EhTRF1 and EhTBP are GAAC-box binding proteins (GBPs). a EMSA using the GAAC-box. Formation of rEhTRF1-GAAC and rEhTBP-GAAC complexes was competed by the unlabeled GAAC-box and TATTTAAA-box (Lanes 3 and 4, and 8 and 9, respectively). b EMSA using the GAAC-like box. The rEhTBP or rEhTRF1 with GAAC-like box forming complex (Lanes 2 and 6). Specific competition with 200-fold molar excess of unlabeled probe (Lanes 3 and 7) or unspecific competition with poly(dl-dC) or (dA-dT) 18 mer oligonucleotide (Lanes 4 and 8, and Lanes 5 and 9, respectively). c, d Mutated GAAC-box was unable to compete the formation of rEhTRF1-GAAC-box and rEhTBP-GAAC-box complexes (Lane 4). e, $\mathbf{f}$ Quantification of the GAAC-box protein complexes as a function of increasing concentrations of rEhTRF1 (e) or rEhTBP (f) by EMSA experiments

d, lane 4). The $K_{D}$ values of rEhTBP and rEhTRF1 for the GAAC-box (Fig. 3a-f) were $(1.90 \pm 0.16) \times 10^{-11} \mathrm{M}$ and $(7.94 \pm 1.44) \times 10^{-11} \mathrm{M}$, respectively (Table 2 ).

\section{Ehtbp gene is overexpressed in nutrient and serum depletion}

The expression of Ehtbp and Ehtrf1 was determined at several points of the growth cycle of E. histolytica in TYI-S-33 medium (Fig. 4). The exponential growth phase began at $36 \mathrm{~h}$ and finished at $72 \mathrm{~h}$. After this time, we observed a decline of $13.0 \%$ and $37.4 \%$ in the viable cell count at 96 and $120 \mathrm{~h}$, respectively, in comparison to the maximum value reached at $72 \mathrm{~h}$ (Fig. 4a). Since there were no changes in the levels of Ehtbp and Ehtrf1 mRNAs at 12, 18 and $36 \mathrm{~h}$ (data not shown), the $36 \mathrm{~h}$ sample was selected as the reference point in our RTqPCR analysis. The Ehtbp gene expression level did not change at $72 \mathrm{~h}$ as well. However, it increased $26 \%$ and $121 \%$ at $96 \mathrm{~h}$ and $120 \mathrm{~h}$, respectively (Fig. 4b). These two points correspond to the decline or death phase of growth curve (Fig. 4a). In the case of Ehtrf1, its mRNA expression level did not significantly change in the growth curve (Fig. 4c). Hence, Ehtbp could play a role in the response to nutrient depletion in trophozoites. 


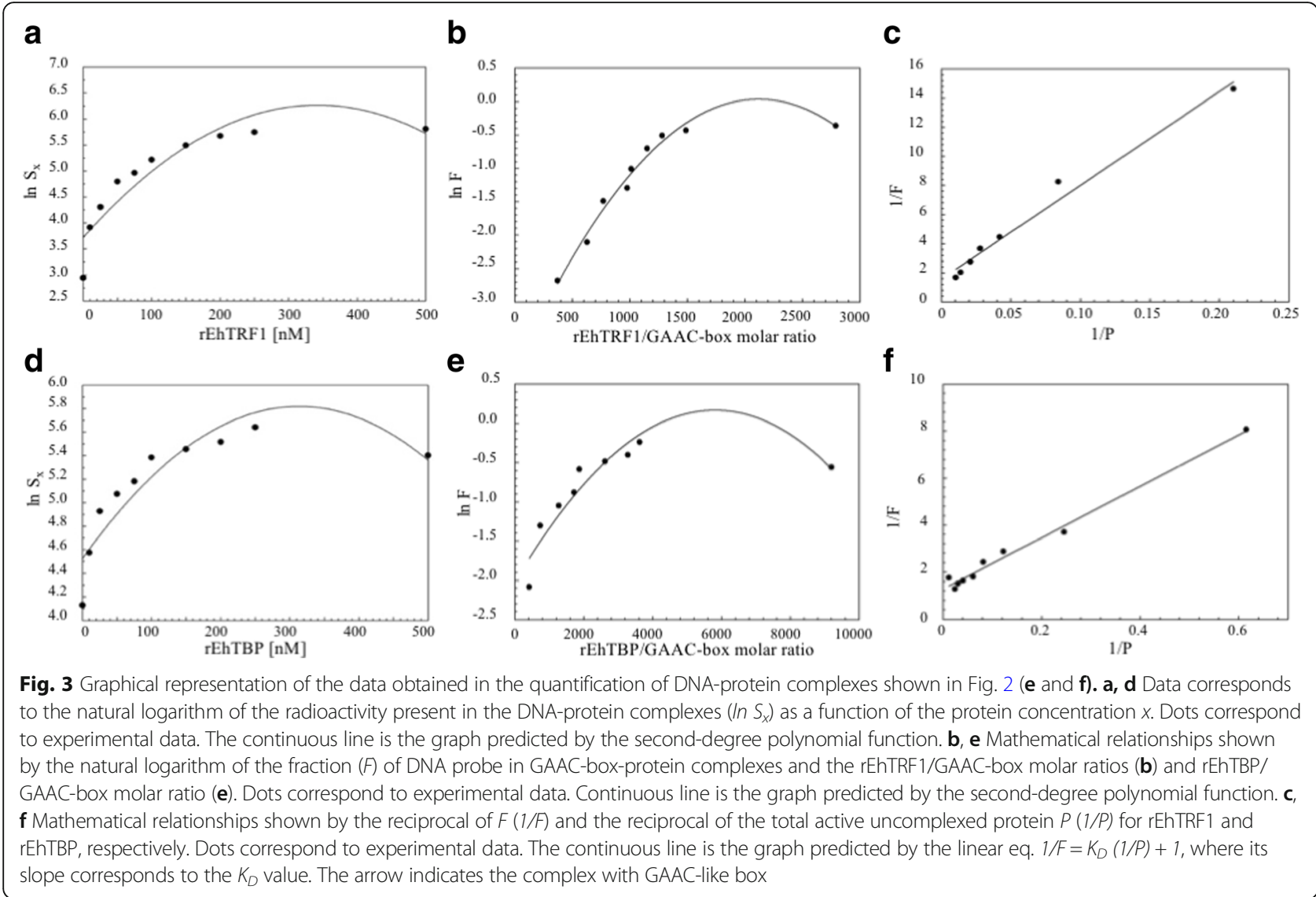

To explore the putative role of Ehtbp, cells were grown in serum-depleted media (Fig. 4). Under this stress condition, cells changed their amoeboid morphology (Fig. 4d) to a round shape (Fig. 4e). In both cases, cell viability was 95\%. When subjected to serum depletion, Ehtbp mRNA levels showed a sharp increase, up to $231 \%$ in comparison

Table 2 Dissociation constants $\left(K_{D}\right)$ of rEhTBP and rEhTRF1 for different TATA variants and GAAC-box

\begin{tabular}{lll}
\hline DNA sequence & rEhTBP & rEhTRF1 \\
\hline TATTTAAA (1) & $(2.07 \pm 0.49) \times 10^{-11} \mathrm{M}$ & $(5.29 \pm 0.98) \times 10^{-11} \mathrm{M}$ \\
TAgTgAAA (2) & $(3.98 \pm 0.16) \times 10^{-11} \mathrm{M}$ & $(1.30 \pm 0.51) \times 10^{-11} \mathrm{M}$ \\
TATTggAA (3) & $(3.57 \pm 0.13) \times 10^{-11} \mathrm{M}$ & $(1.35 \pm 0.88) \times 10^{-11} \mathrm{M}$ \\
TATTaAAA (4) & $(4.85 \pm 3.06) \times 10^{-12} \mathrm{M}$ & $(3.98 \pm 1.96) \times 10^{-12} \mathrm{M}$ \\
TATgTAAA (5) & $(1.69 \pm 1.37) \times 10^{-12} \mathrm{M}$ & $(6.74 \pm 2.25) \times 10^{-12} \mathrm{M}$ \\
gAgTTAAA (6) & $(4.73 \pm 2.91) \times 10^{-12} \mathrm{M}$ & $(6.85 \pm 4.77) \times 10^{-12} \mathrm{M}$ \\
TACTCAAA (7) & $(2.76 \pm 1.48) \times 10^{-12} \mathrm{M}$ & $(2.98 \pm 1.37) \times 10^{-11} \mathrm{M}$ \\
CACTCAAA (8) & $(3.80 \pm 1.46) \times 10^{-11} \mathrm{M}$ & $(3.08 \pm 1.15) \times 10^{-11} \mathrm{M}$ \\
CAcTTAAA (9) & $\mathrm{NB}$ & $(9.72 \pm 4.88) \times 10^{-12} \mathrm{M}$ \\
TATTTtt (10) & $(3.40 \pm 1.64) \times 10^{-12} \mathrm{M}$ & $(2.54 \pm 1.37) \times 10^{-11} \mathrm{M}$ \\
GAAC-box & $(1.90 \pm 0.16) \times 10^{-11} \mathrm{M}$ & $(7.94 \pm 1.44) \times 10^{-11} \mathrm{M}$ \\
\hline AbtreVaton $N B$ Do &
\end{tabular}

Abbreviation: NB No binding activity for this DNA sequence to normal conditions. Meanwhile, Ehtrf1 expression did not show any significant changes (Fig. 4f).

We also immunolocalized EhTBP at the same time points of the growth curve and during serum depletion (Fig. 5 and Additional file 4: Figure S2). In the initial growth phase (0 to $36 \mathrm{~h}$ ), EhTBP was mainly localized in the nucleus, while at $72 \mathrm{~h}$, it was also observed in the cytoplasm. During decline phase at 96 and $120 \mathrm{~h}$, this protein was detected both in the cytoplasm and nucleus (Fig. 5a). During serum depletion, EhTBP was localized both in cytoplasm and nucleus, while in the presence of serum, it was only observed in the nucleus (Fig. 5b).

\section{Ehtrf1 gene expression is negatively regulated during UV- irradiation and heat-shock stress}

Transcription of Ehtbp remained unchanged up to 30 min following UV irradiation (Fig. 6a). However, Ehtrf1 transcription significantly diminished to 0.57 and 0.45 at 15 and $30 \mathrm{~min}$ after UV exposure, respectively, in comparison to non-irradiated cells (Fig. 6b). We determined the transcription levels of Ehrad54, Ehblm and Ehpcna genes in this experiment as reference genes because they are UV-responsive genes and are involved in DNA repair [38, 39]. In the case of Ehrad54, it showed a 


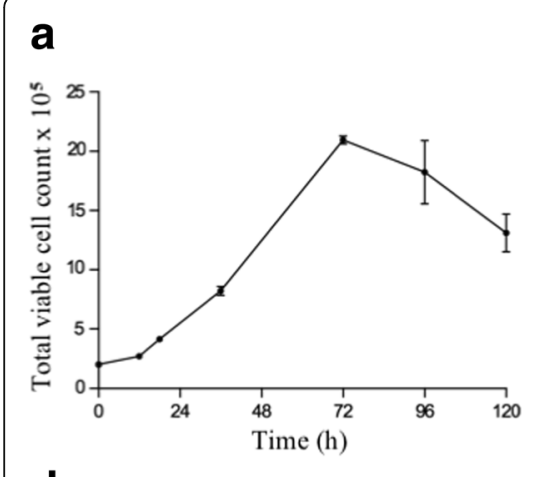

d

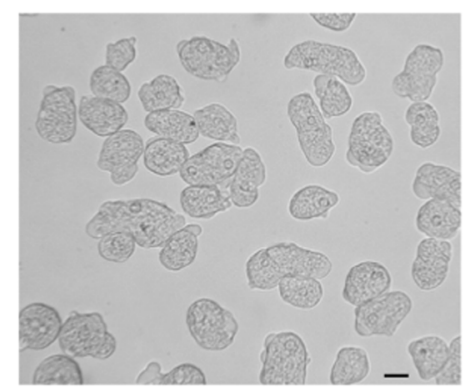

(+) Serum

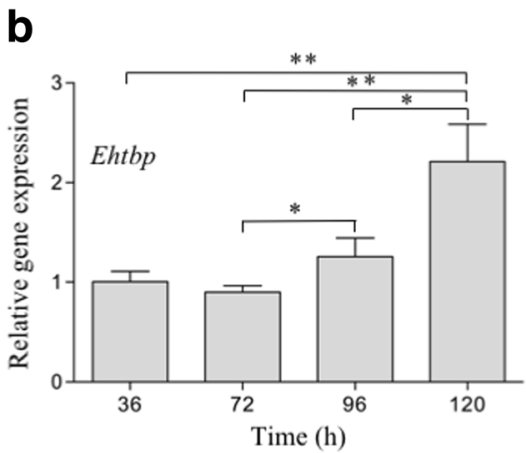

e

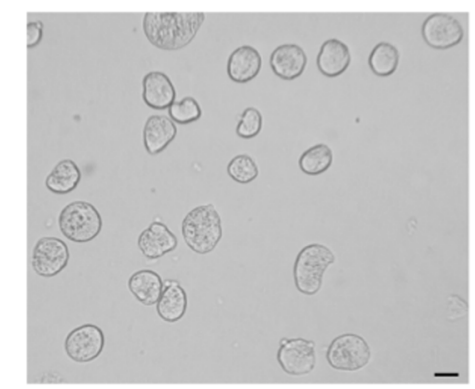

(-) Serum
C

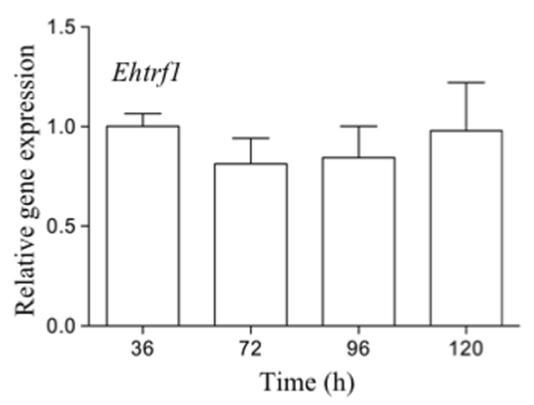

f

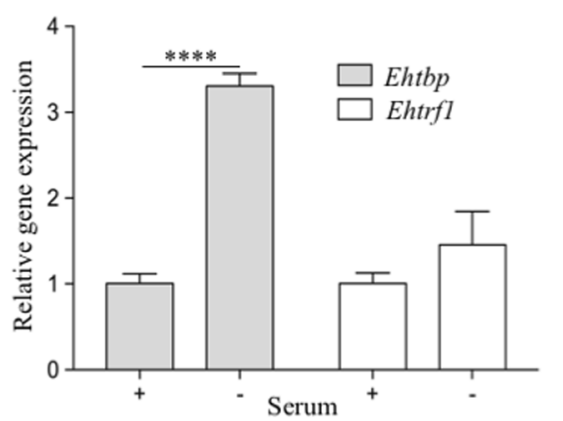

Fig. 4 Ehtbp is upregulated during nutrient deprivation. a Growth curve of trophozoites at 12, 18, 36, 72, 96 and 120 h. b, c Relative gene expression levels of Ehtbp (b) and Ehtrf1 (c) at different times of growth curve. Statistical significance (Student's t-test) defined as * $P<0.05$, ** $P<0.001$. d, e Images of trophozoites grown in TYI-S-33 medium for $12 \mathrm{~h}$ at $37{ }^{\circ} \mathrm{C}$ with serum (d) or without serum (e). Photomicrographs were obtained with a magnification of $200 \times$. $\mathbf{f}$ RT-qPCR analysis of Ehtbp and Ehtrfi genes. Statistical significance was determined using the Student's t-test (**** $P<0.0001)$. Scale-bar: $10 \mu \mathrm{m}$

decrease to $0.61,0.49$ and 0.32 transcription level at 5, 15 and $30 \mathrm{~min}$, respectively (Fig. 6c). Ehblm also showed a decrease to 0.55 and 0.31 at 5 and $30 \mathrm{~min}$ after UV irradiation, respectively (Fig. 6d). Finally, the Ehpcna mRNA level diminished to 0.72 after 30 min of UV exposure (Fig. 6e). Results obtained for Ehrad54 mRNA level were similar to those previously reported [38]. In contrast to this, while the Ehblm mRNA level decreased in our case, the EhBLM protein level increased 2-fold and 34-fold at 5 and $30 \mathrm{~min}$ in cytoplasmic extracts, respectively [39]. It is important to note that cell viability after UV-irradiation was 97\% by trypan blue exclusion assay.

Trophozoites that were incubated at $42{ }^{\circ} \mathrm{C}$ for $4 \mathrm{~h}$ showed no change in their cellular morphology (data not shown). The cell viability was $95 \%$ following heatshock. Trophozoites in this stress condition showed no change in the Ehtbp mRNA transcription level. However, the Ehtrf1 mRNA level was reduced to $33 \%$ in comparison to its transcription under standard growth conditions (Fig. 6f). To corroborate the heatshock stress response, the gene expression level of Ehhsp70 was determined, displaying 35-fold increase at $42{ }^{\circ} \mathrm{C}$ (Fig. 6g).

\section{Ehtrf1 and Ehtbp gene expression levels are downregulated during erythrophagocytosis}

During erythrophagocytosis, trophozoites ingested increasing numbers of RBCs as a function of time, reaching an average of 12 ingested erythrocytes per trophozoite in $30 \mathrm{~min}$ (Fig. 7a, b). To determine the count, one hundred randomly selected trophozoites were counted at each time interval and the data were plotted to calculate the average of ingested erythrocytes per trophozoite (Fig. 7b). Interestingly, the Ehtbp mRNA transcription level slightly diminished to 0.77 and 0.73 at 15 and $30 \mathrm{~min}$, respectively, while Ehtrf1 transcription level significantly decreased to $0.47,0.39$ and 0.33 at 10 , 15 and $30 \mathrm{~min}$, respectively (Fig. 7c, d, respectively).

\section{Ehtrf1 gene expression is transiently upregulated during MDCK cell monolayer destruction}

The other virulence condition tested was the incubation of trophozoites with MDCK epithelial cell monolayers at different times. An intact MDCK cell monolayer was homogeneously stained with methylene blue (Fig. 7e, 0 min). However, when trophozoites were incubated with the cell monolayer, the destruction was evidenced by clear unstained areas, which increased with time (Fig. 


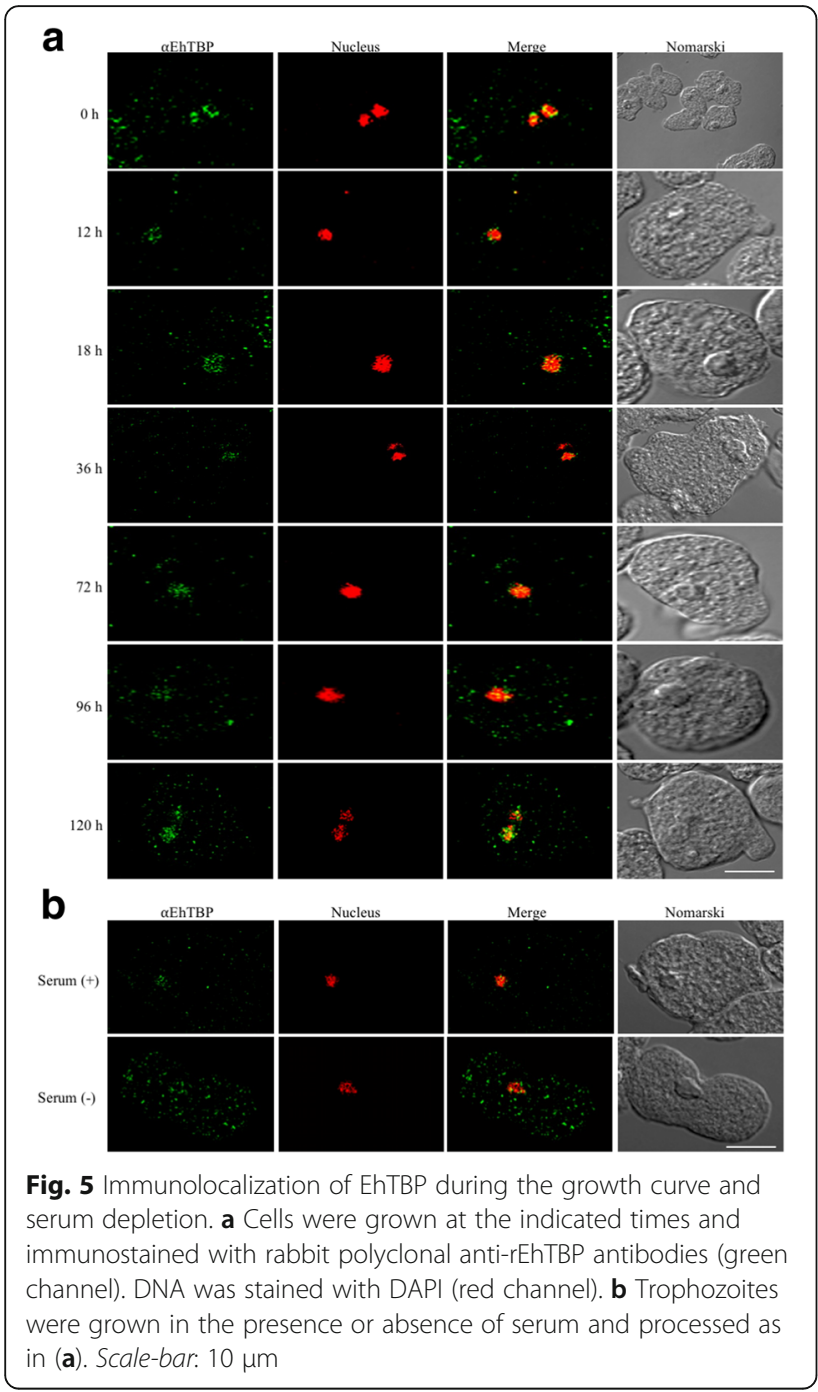

7e). The percentage of monolayer destruction was $15.5 \%, 35 \%$ and $64 \%$ at 5,15 and $30 \mathrm{~min}$ respectively (Fig. 7e). In these conditions, the Ehtbp transcription level remained unchanged through all the tested time intervals (Fig. 7f). However, the Ehtrf1 transcription level showed a transient increase up to 2.5 -fold at $5 \mathrm{~min}$ of interaction with MDCK cell monolayer, decreasing to its normal transcription level at 15 and $30 \mathrm{~min}$ in comparison to the 0 min condition (Fig. $7 \mathrm{~g}$ ).

\section{Ehtrf1 is downregulated in trophozoites isolated from amoebic hepatic abscesses}

We determined the mRNA levels of Ehtbp and Ehtrf1 before and after the formation of liver abscesses in hamsters. After one week in the liver, trophozoites formed a huge number of small amoebic liver abscesses (ALA) (Fig. 8b) in comparison to normal liver (NL) (Fig. 8a). Trophozoites that were recovered by shredding the liver into small pieces and incubation for 3 to 4 days in TYI-
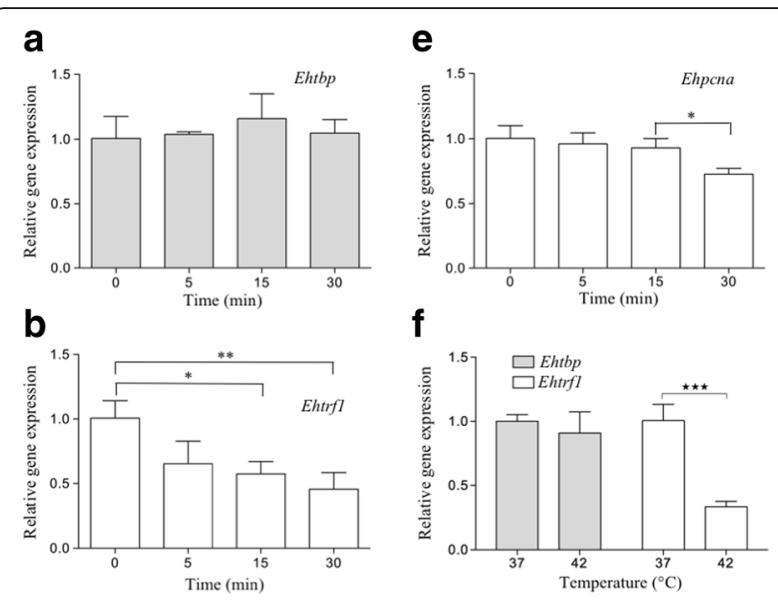

f
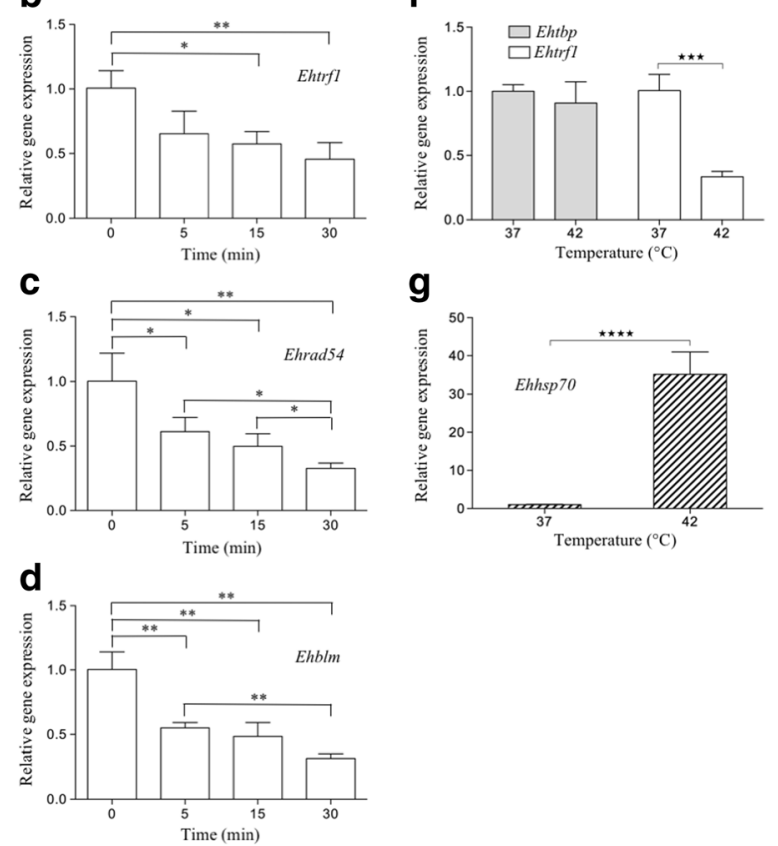

Fig. 6 Ehtrf1 is downregulated in response to UV irradiation and heat-shock stress. UV-irradiation a-e Relative gene expression of Ehtbp (a), Ehtrf1 (b), Ehrad54 (c), Ehblm (d) and Ehpcna (e) normalized with the endogenous gene control Eh40Ss2. f Gene expression analysis of Ehtbp and Ehtrf1 by RT-qPCR in trophozoites cultured at $37^{\circ} \mathrm{C}$ and $42^{\circ} \mathrm{C}$ as described. $\mathbf{g}$ As a control of heat-shock response, the expression level of Ehhsp70 gene was determined. No change in morphology was observed in both cases. Significant values are marked with asterisks (Student's t-test, ${ }^{*} P<0.05$, ${ }^{* *} P<0.001$, ${ }^{* * *} P<0.0005$ )

S-33 medium showed no change in the transcription level of Ehtbp in comparison to trophozoites that had been kept in laboratory conditions (NT) for at least four months (Fig. 8c). However, the Ehtrf1 mRNA level significantly diminished to 0.58 after recovery from liver abscess (Fig. 8c). Therefore, the combined transcriptional expression analysis (erythrophagocytosis, MDCK cell destruction and liver abscess) reveals that the Ehtrf1 gene might have a role in virulence conditions.

\section{Ehtbp gene knockdown affects the rate of} erythrophagocytosis in E. histolytica G3 trophozoites

In higher eukaryotes, TBP is considered vital for gene regulation [28]. To evaluate the importance of Ehtbp, we used G3 trophozoites and psAP2 vector for gene knockdown. Stable transfectants of Ehtbp were obtained by 
a

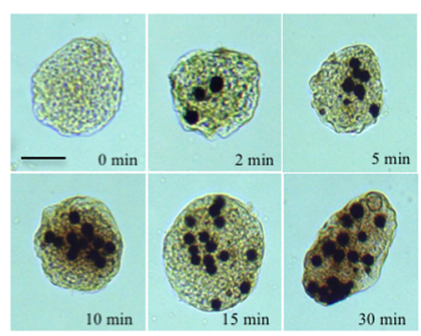

C

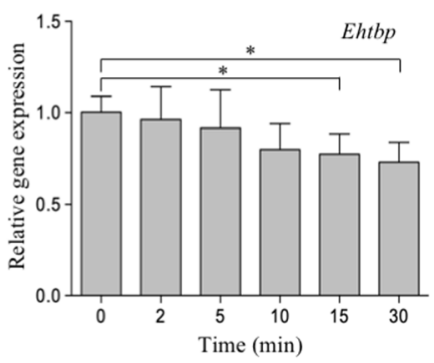

e

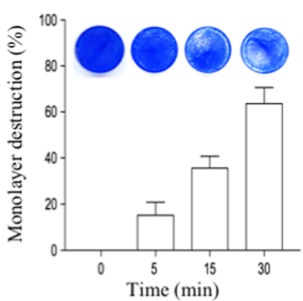

b

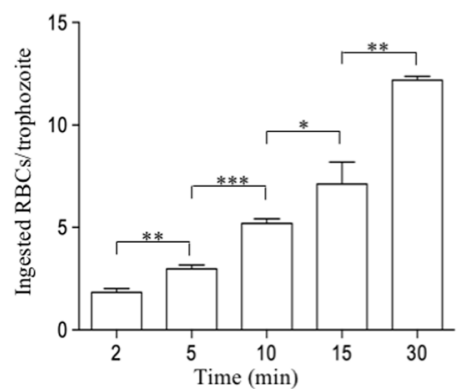

d

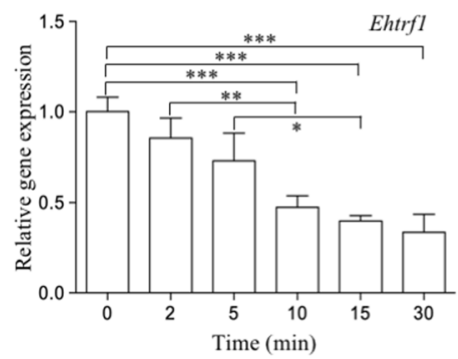

g
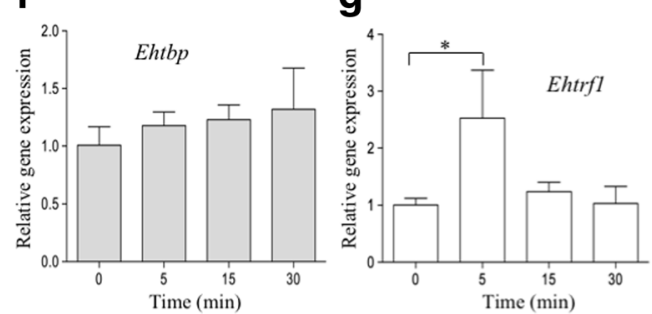

Fig. 7 Gene expression analyses of Ehtrf1 and Ehtbp genes of E. histolytica trophozoites during erythrophagocytosis and MDCK monolayer destruction and amoebic abscess formation. a-d Erythrophagocytosis assay. a Representative photomicrographs showing the accumulation of ingested erythrocytes in trophozoites at different time points. Photomicrographs were taken at 200x magnification. b Graph showing the average number of ingested erythrocytes by trophozoites. c, $\mathbf{d}$ Gene expression levels of Ehtbp (c) and Ehtrfi (d). e-g MDCK cell monolayer destruction by trophozoites. e Images of representative culture plates of stained MDCK cell monolayers destroyed by live trophozoites interacting for 5, 15 and $30 \mathrm{~min}$. An intact MDCK cell monolayer is shown (0 min) for comparison. f, g RT-qPCR analysis of Ehtbp and Ehtrfl genes, respectively. Statistical analysis with significant difference are marked with asterisks (Student's t-test, ${ }^{*} P<0.05,{ }^{* *} P<0.001,{ }^{* * *} P<0.0003$ ). Scale-bar: $10 \mu \mathrm{m}$

a

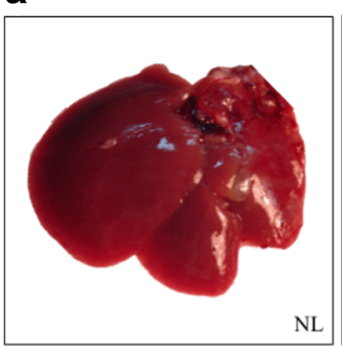

b

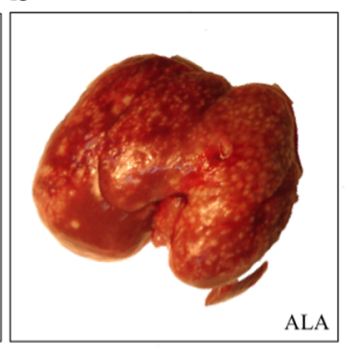

C

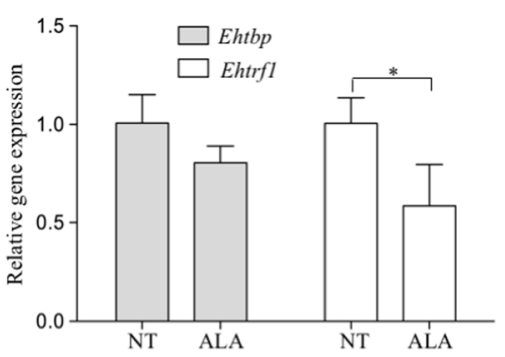

Fig. 8 Gene expression analyses of Ehtrf1 and Ehtbp genes of E. histolytica trophozoites during amoebic abscess formation. a, b Images of normal liver (NL) and with a number of amoebic liver abscesses (ALA), respectively. c Gene expression analysis of Ehtbp and Ehtrf1 genes in trophozoites grown in normal conditions (NT) or isolated from amoebic liver abscesses (ALA). Statistical analysis with significant difference is marked with an asterisk (Student's t-test, ${ }^{*} P<0.05$ ) 
incubation with G418 at 3, 5 and $10 \mu \mathrm{g} / \mathrm{ml}$ for at least two months. Through RT-qPCR analysis, we observed a 50\% decrease in Ehtbp transcription across all tested drug concentrations in comparison to control cells transfected with the empty plasmid (Fig. 9a). To characterize the phenotype of Ehtbp KD G3 trophozoites, we obtained the growth curves of G3 cells, G3 transfected with psAP2 empty vector, and G3 Ehtbp KD cells in TYI-S-33 medium (Additional file 5: Figure S3). We did not observe any growth defects or morphological changes in trophozoites under this condition. In serum depletion experiments with G3 Ehtbp KD trophozoites, we did not observe morphological changes in cells as well (data not shown). It has been previously reported that closely related genes might also be silenced when the primary target is silenced using this strategy [44], but we observed no change in the transcription of Ehtrf1 in the Ehtbp knockdown strain (Fig. 9b). The Ehtrf1 gene knockdown was unsuccessful after several attempts using different strategies. Subsequently, we performed erythrophagocytosis assays to evaluate whether the silencing of Ehtbp had any impact on virulence (Fig. 9c). The assay was carried out with the Ehtbp knockdown trophozoites grown at $10 \mu \mathrm{g} / \mathrm{ml} \mathrm{G418}$ and cells transfected with empty vector as a control. The mean number of ingested erythrocytes was gradually increased from 2 (2 $\mathrm{min})$ to 10 (30 $\mathrm{min})$ in G3 control cells
(Fig. 9c), while in the case of Ehtbp knockdown cells a lower mean number of ingested erythrocytes was observed, from 1 (at $2 \mathrm{~min}$ ) to 4 (at $30 \mathrm{~min}$ ) (Fig. 9c), indicating that the knocking down of Ehtbp gene reduced the rate of erythrophagocytosis. Transcription of the Ehvps32 and EhrabB genes previously reported as being involved in phagocytosis was also evaluated in Ehtbp knockdown cells [45, 46]. However, both genes did not show any significant change in their mRNA levels (Additional file 5: Figure S3b).

Using the software described by Meneses et al. [16], we selected two genes containing only the GAAC motif to measure their mRNA levels by RT-qPCR in Ehtbp knockdown cells. The Ehrho (EHI_190440) gene promoter contains a GAAC-box at -63 to -56 , while the Ehhgl (EHI_012270) promoter has the GAAC box at -57 to -50 from the corresponding theoretical transcription start sites. We observed no changes for the Ehrho gene. However, the mRNA amount of Ehhgl decreased 67\% (Fig. 9d). These differences indicate the Ehhgl is being regulated by Ehtbp, while Ehrho gene might be controlled by other transcription factors.

\section{Discussion}

In the present study, the DNA-binding activity of rEhTBP and rEhTRF1 polypeptides for different TATA variants was determined (Fig. 1 and Additional file 3:
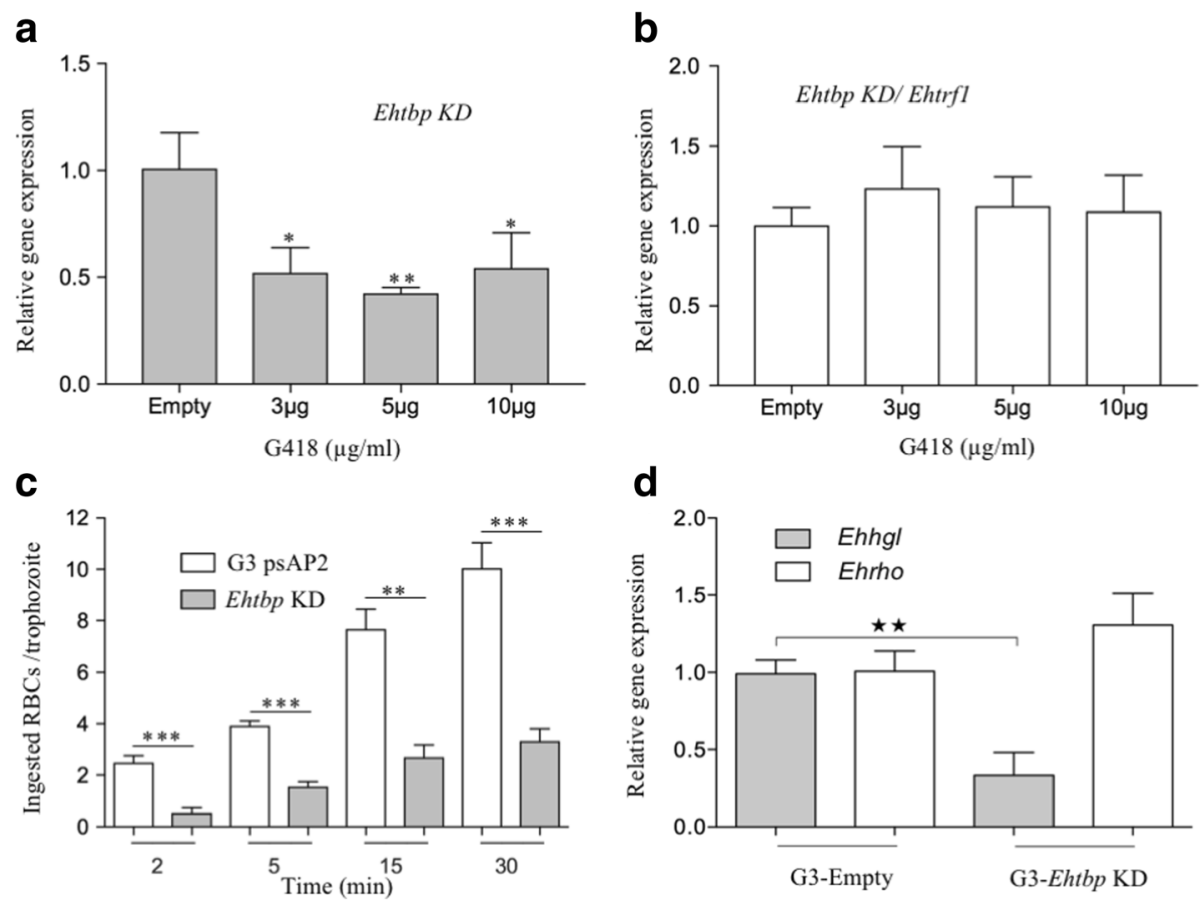

Fig. 9 Ehtbp gene knockdown using G3 trophozoites. a Gene expression analysis of Ehtbp in knocked down (KD) cells grown at 3, 5, 10 $\mu \mathrm{g} / \mathrm{ml}$ G418, using transfected cells with empty vector as a control. b Gene expression analysis of Ehtrf1 gene in Ehtbp knockdown cells. c Number of ingested erythrocytes at 2, 5, 15 and 30 min in control G3 cells and $10 \mu \mathrm{g} / \mathrm{ml} \mathrm{G418} \mathrm{Ehtbp} \mathrm{knockdown} \mathrm{cells.} \mathrm{d} \mathrm{Gene} \mathrm{expression} \mathrm{analysis} \mathrm{of} \mathrm{two}$ genes containing the GAAC motif (Ehhgl, Ehrho) in Ehtbp KD cells. Significant difference was measured using Student's t-test and marked with asterisks $\left(* P<0.05,{ }^{* *} P<0.002,{ }^{* * *} P<0.0004\right)$ 
Figure S1). Remarkably, rEhTRF1 bound all the TATA variants assayed, while rEhTBP bound all but the cAcTTAAA (9) variant. $K_{D}$ values were in the range of 10 ${ }^{12} \mathrm{M}$ to $10^{-11} \mathrm{M}$ for both transcription factors (Table 2, Additional file 6: Table S2, and Additional file 7: Table S3). Thus, in combining the results obtained before [19, 30] with those obtained in this study, the proposed $E$. histolytica TATA-box motif is defined as follows: $5^{\prime}$ (1: T/G/C) (2: A) (3: T/G/C) $(4: \mathrm{A} / \mathrm{T} / \mathrm{G})(5: \mathrm{A} / \mathrm{T} / \mathrm{G} / \mathrm{C})$ (6: $\mathrm{A} / \mathrm{T} / \mathrm{G})(7: \mathrm{A} / \mathrm{T})(8: \mathrm{A} / \mathrm{T})$, where numbers in parenthesis indicate the position in TATA sequence, and the nucleotide in bold was only assayed for rEhTBP. Remarkably, the presence of two C's in positions 1 and 3 abolished the DNA-binding capacity of rEhTBP only, which was rescued when a third $C$ was in position 5 .

In addition to the TATA-box and Inr sequences, a third unusual core promoter element named GAAC element has only been reported in E. histolytica [4, 47]. EMSA analysis revealed that both rEhTBP and rEhTRF1 bound the GAAC-box (Fig. 2) with $K_{D}$ values of $10^{-11} \mathrm{M}$ (Table 2). This element was identified in 31 gene promoters of 37 genes studied. Furthermore, other studies have confirmed that the GAAC-box controls both the expression rate and location of the transcription initiation start site [4]. A nuclear GAAC-box binding protein (GBP) of $29 \mathrm{kDa}$ has been detected, but its identity remains unknown [47]. As the molecular masses of EhTBP and EhTRF1 are $26 \mathrm{kDa}$ and $24 \mathrm{kDa}$, respectively, both proteins might be feasible candidates of GBPs, recruiting to promoters the TFIID complex and other basal transcription factors to assemble the pre-initiation complex [48]. Furthermore, both transcription factors showed binding capacity to the GAAC-like box, which has been found widely distributed in gene promoters of $E$. histolytica [17]. This is the first experimental study to demonstrate the binding capacity of the EhTBP and EhTRF1 transcription factors to both GAAC and GAAC-like boxes.

In higher eukaryotes, TBP is involved in transcription mediated by the three RNA polymerases. TBP-related factors have evolved in species as a form of specialization that allows the expression of sets of genes for determining biological functions. However, they have only been found in multicellular organisms possessing specialized cells, e.g. spermatids and oocytes. It seems feasible that the different sets of genes that $E$. histolytica employs to perform its specialized functions, including adhesion, host cell lysis, phagocytosis [33, 49], trogocytosis [50], encystment, response to stress conditions, etc. are under the control of master genes that coordinately regulates them. Several studies have allowed the identification of stress-related transcription factors in response to external perturbations. However, the role of basal transcription factors under those stringent conditions remains unclear. In this work, we determined the Ehtbp and Ehtrf1 mRNA levels under different conditions intimately linked to parasite's virulence, as well as those related to stress responses.

The first condition tested was throughout the growth in laboratory conditions. During the decline phase, abnormal spherically shaped cells were observed, losing surface adherence and amoeboid movement (data not shown). Interestingly, the Ehtbp mRNA level was nearly doubled at $120 \mathrm{~h}$ in comparison to the previous sample at $96 \mathrm{~h}$, suggesting a possible role in the parasites' response to nutrient deprivation (Fig. 4). When subjected to serum depletion, similar morphological changes were observed (Fig. 4e). Under this stress condition, the mRNA level of Ehtbp increased up to $231 \%$ compared to the control (Fig. 4f). This remarkable increase in the Ehtbp gene mRNA level led us to speculate that it behaves as a serum responsive factor during nutrient depletion by regulating an unknown group of genes on demand. We observed an increase in EhTBP protein level both in the nucleus and cytoplasm, which correlates with the upregulation of the mRNA level of Ehtbp under both stress conditions (Fig. 5 and Additional file 4: Figure S2). In contrast, Homo sapiens tbp (Hstbp) maintained a constitutive expression in serum starved quiescent cells, while an increase in the mRNA level of this gene was observed 15 min after serum stimulation [51]. In our study, Ehtrf1 marked a constitutive expression throughout growth and serum depletion stress. However, TRF2 negatively regulates the cell cycle progression rate and is dispensable for the transition through the G2 phase in DT40 chicken cells [52]. A recent study on E. histolytica reports a long noncoding RNA (EhslncRNA), which responds to serum depletion at $24 \mathrm{~h}$ [53]. Our findings reveal that Ehtbp has an initial response at $12 \mathrm{~h}$ though the analysis of later timepoints in future studies will be crucial to understanding the role of this gene in the E. histolytica biology.

Acute stress provokes in cells sudden changes in the transcriptional profile to respond to external stimuli [54]. In the case of trophozoites under heat-shock stress at $42{ }^{\circ} \mathrm{C}$, we observed a negative regulation of Ehtrf1, which demands an in-depth study about its role in heatshock stress. In the UV irradiation experiment, Ehtbp showed a basal mRNA level throughout the recovery time intervals. However, it might have a role in the UVstress response, because TBP in other systems has more preference for binding damaged DNA induced by UVirradiation than controlling transcriptional initiation [55]. The negative regulation of the mRNA level of Ehtrf1 suggests that some responsive factors bind to Ehtrf1 promoter responsive elements to provoke its decreased transcription, with the subsequent induction of genes involved in the UV damage response. This could be similar to the role of TRF2 in the induction of a transient change in a limited group of genes under UV- 
irradiation of DT40 cells [53]. We also determined the mRNA transcription levels of Ehrad54, Ehblm, Ehpcna genes which are involved in the response to UVirradiation. The Ehblm gene displayed a similar expression pattern to that of Ehtrf1. However, this result is contrary to the increase in the amount of the Ehblm protein observed by others [39], which could be explained by an augment in the efficiency of Ehblm mRNA translation or an increase in the half-life of the protein through interactions with other proteins or due to posttranslational modifications [56].

Entamoeba histolytica is well known for its virulence properties such as phagocytosis, host cell lysis and organ invasion for abscess formation. Erythrocytes are excellent target cells to study phagocytosis. Our results showed an engulfment capacity of 12 erythrocytes on average at $30 \mathrm{~min}$. A slight decrease in the mRNA of Ehtbp was observed at 15 and $30 \mathrm{~min}$. In the case of Ehtrf1, a well-noted decrease in the mRNA level was observed from 10 to $30 \mathrm{~min}$ due to unknown factors. This result led us to analyze their expression pattern in other virulence conditions. Analyzing the cytopathic effect is crucial for understanding the pathogenesis of this parasite during host cell invasion. In order to simulate the condition, we selected the MDCK cell line, the best model to study as a human epithelial barrier [57]. When live trophozoites were laid over the MDCK cell monolayer, the Ehtbp gene showed no change in its mRNA level whilst Ehtrf1 had a transient increase at 5 min only.

Inside the host, abscesses first appear in the liver and dislodgement of virulent trophozoites occurs to acquire the other organs of the host [58]. Gilchrist et al. [59] showed in microarray analysis the negative regulation of Ehtbp both at days 1 and 29 during mice intestinal amoebic infection. However, trophozoites isolated from liver abscesses and cultured for $16 \mathrm{~h}$ showed a two-fold overexpression of Ehtbp, with no changes in Ehtrf1 mRNA level [60]. In our case, trophozoites obtained from amoebic liver abscesses and cultured for 3-4 days, showed an unaltered Ehtbp mRNA level and downregulation of Ehtrf1. This result could be due to the shift from a solid tissue environment (hepatic liver) to TYI-S33 medium.

Several approaches using siRNAs and ribozymes were intended to knockdown these transcription factors, but it was only successful with G3 trophozoites using the vector psAP2 for the Ehtbp gene [61, 62]. The main characteristics of the G3 strain are erythrophagocytosis and the incapability of cell monolayer destruction or abscess formation [62]. The significant decrease in the transcription level of Ehtbp silenced cells (Fig. 9a) greatly affected the rate of erythrophagocytosis (Fig. 9c). Moreover, we did not observe any growth defects (Additional file 5: Figure S3a) or morphological changes in trophozoites under this condition and in serum deprivation (data not shown). The reduction in the mRNA amount of Ehtbp might affect the expression of genes involved in erythrophagocytosis. However, the EhrabB and Ehvps32 genes involved in phagocytosis were unaffected (Additional file 5: Figure S3b). The former has a GAAC motif at 22 to 29 bases upstream the ATG translation start site, but no TATA nor Inr boxes were identified [63]. The latter has a GAAC motif at -32 to -29 upstream the ATG codon site with no TATA and Inr consensus sequences. Two other genes (Ehhgl and Ehrho) containing the GAAC-box were evaluated by RTqPCR, but only the Ehhgl diminished its mRNA level (Fig. $8 \mathrm{~d})$. This differential gene regulation suggests a specific subset of genes under the control of Ehtbp and Ehtrf1, which requires an extensive microarray analysis to comprehend and unveil the list of participating genes in phagocytosis or other physiological conditions.

For unknown reasons, the Ehtrfl gene was unable to get silenced in G3 trophozoites (data not shown). In addition, the use of specific antibodies against EhTBP and EhTRF1 to determine their protein expression levels has been elusive because both proteins are highly conserved. Even though we have eleven monoclonal antibodies for each protein, they recognized both polypeptides by Western blot (data not shown). This impedes the further use of antibodies for advanced techniques like chromatin immunoprecipitation experiments.

\section{Conclusions}

EhTBP and EhTRF1 are two promiscuous transcription factors that displayed the DNA-binding capacity of diverse core promoter elements, including the GAAC-box, revealing them as putative GBPs. Remarkably, the differential expression observed under different stress stimuli and during the interaction with mammalian cells opens the possibility to evaluate key factors behind these phenomena. Targeting the signaling pathway during stringent conditions would unveil the transcriptional flexibility of these basal transcription factors and their selective response. Thus, elucidation of these basal transcription factors in response to those external insults will be useful to understanding the gene regulatory networks of this unicellular protozoan parasite. Hence, this study broadly opens the state of investigation, suggesting transcriptome analysis using either microarray analysis or next-generation sequencing to address the genes underregulation of these transcription factors in E. histolytica.

\section{Additional files}

Additional file 1: Method for the calculation of dissociation constant values. (DOCX $20 \mathrm{~kb}$ ) 
Additional file 2: Table S1. Primers used for the amplification of selected genes. (DOCX $15 \mathrm{~kb}$ )

Additional file 3: Figure. S1. Quantification of DNA-protein complexes. (TIFF $552 \mathrm{~kb}$ )

Additional file 4: Figure S2. Immunolocalization of EhTBP in trophozoites during the growth culture (a) and serum depletion (b). (TIFF $371 \mathrm{~kb}$ )

Additional file 5: Figure S3. The Ehtbp knockdown does not affect the growth of G3 trophozoites. (TIFF $91 \mathrm{~kb}$ )

Additional file 6: Table S2. Coefficients of equations for rEhTBP/DNA probe. (DOCX $18 \mathrm{~kb}$ )

Additional file 7: Table S3. Coefficients of equations for rEhTRF1/DNA probe. (DOCX $21 \mathrm{~kb}$ )

\section{Abbreviations}

ALA: Amebic liver abscess; EMSA: Electrophoretic mobility shift assay; GBP: GAAC-box binding protein; $K_{D}$ : Dissociation constant; MDCK: MadinDarby canine kidney; NT: Normal trophozoites; TBP: TATA-box binding protein; TRF1: TBP-related factor 1

\section{Acknowledgements}

The authors thank José Manuel Galindo Rosales and Hernández De Jesús Selene for their technical assistance.

\section{Funding}

We are grateful to the National Council of Science and Technology of Mexico (CONACyT) for the support to this work with the Grant number CB2009-132020-B to Dr Juan Pedro Luna Arias, and for the PhD fellowship to Ravi Kumar Narayanasamy (CVU 420549).

\section{Availability of data and materials}

The authors declare that the data supporting the findings of this study are available from the article and its supplementary information files.

\section{Authors' contributions}

Conceived and designed the study: RKN, EO and JPLA. Performed the experiments: RKN, CACS, GGR, BAB and MLLB. Analyzed the data: RKN, CACS, EO, JV, MEHA and JPLA. Contributed reagents/materials/analysis tools: JPLA, EO and JV. Wrote the paper: RKN, EO and JPLA. All authors read and approved the final manuscript.

\section{Ethics approval and consent to participate}

The Institutional Animal Care and Use Committee (IACUC) ethics committee reviewed and approved the animal care and use of hamsters in in vivo experiments. The institutional animal breeding facility fulfills the international regulations for the animal use and care (CINVESTAV Approval Number: BOO.02.03.02.01.908)

\section{Consent for publication}

Not applicable.

\section{Competing interests}

The authors declare that they have no competing interests.

\section{Publisher's Note}

Springer Nature remains neutral with regard to jurisdictional claims in published maps and institutional affiliations.

\section{Author details}

${ }^{1}$ Departamento de Infectómica y Patogénesis Molecular, Centro de Investigación y de Estudios Avanzados del Instituto Politécnico Nacional (Cinvestav-IPN), Av. Instituto Politécnico Nacional 2508, Col. San Pedro Zacatenco, C.P, 07360 Ciudad de México, Mexico. ${ }^{2}$ Programa de Biomedicina Molecular, Escuela Nacional de Medicina y Homeopatía del Instituto Politécnico Nacional (ENMH-IPN), Guillermo Massieu Helguera 239, Col. La Escalera, C.P, 07320 Ciudad de México, Mexico. ${ }^{3}$ Laboratorio de Investigación Biomédica, Subdirección de Enseñanza e Investigación, Hospital Regional de Alta Especialidad de Oaxaca, Aldama S/N, San Bartolo Coyotepec, C.P, 71256 Oaxaca, Mexico. ${ }^{4}$ Departamento de Biología Celular, Centro de Investigación y de Estudios Avanzados del Instituto Politécnico Nacional (Cinvestav-IPN), Av. Instituto Politécnico Nacional 2508, Col. San Pedro Zacatenco, C.P, 07360 Ciudad de México, Mexico. ${ }^{5}$ Departamento de Bioquímica, Centro de Investigación y de Estudios Avanzados del Instituto Politécnico Nacional (Cinvestav-IPN), Av. Instituto Politécnico Nacional 2508, Col. San Pedro Zacatenco, C.P, 07360 Ciudad de México, Mexico.

Received: 26 April 2017 Accepted: 2 February 2018

Published online: 07 March 2018

\section{References}

1. Ali IK, Clark CG, Petri WA. Molecular epidemiology of amebiasis. Infect Genet Evol. 2008:8:698-707.

2. Loftus B, Anderson I, Davies R, Alsmark UCM, Samuelson J, Amedeo P, Hall $\mathrm{N}$. The genome of the protist parasite Entamoeba histolytica. Nature. 2005; 433.865-8.

3. Lorenzi HA, Puiu D, Miller JR, Brinkac LM, Amedeo P, Hall N, Caler EV. New assembly, reannotation and analysis of the Entamoeba histolytica genome reveal new genomic features and protein content information. PLoS Negl Trop Dis. 2010:4:e716.

4. Singh $U$, Rogers JB, Mann BJ, Petri WA. Transcription initiation is controlled by three core promoter elements in the hgl5 gene of the protozoan parasite Entamoeba histolytica. Proc Natl Acad Sci USA. 1997;94:8812-7.

5. Gilchrist CA, Mann BJ, Petri WA. Control of ferredoxin and gal/GalNAc lectin gene expression in Entamoeba histolytica by a cis-acting DNA sequence. Infect Immun. 1998;66:2383-6.

6. Gomez C, Perez DG, Lopez-Bayghen E, Orozco E. Transcriptional analysis of the EhPgp1 promoter of Entamoeba histolytica multidrug-resistant mutant. J Biol Chem. 1998:273:7277-84

7. Lopez-Camarillo C, Luna-Arias JP, Marchat LA, Orozco E. EhPgp5 mRNA stability is a regulatory event in the Entamoeba histolytica multidrug resistance phenotype. J Biol Chem. 2003;278:11273-80.

8. Edman U, Meza I, Agabian N. Genomic and cDNA actin sequences from a virulent strain of Entamoeba histolytica. Proc Natl Acad Sci USA. 1987;84: 3024-8.

9. Pearson RJ, Morf $L$, Singh U. Regulation of $\mathrm{H}_{2} \mathrm{O}_{2}$ stress-responsive genes through a novel transcription factor in the protozoan pathogen Entamoebo histolytica. J Biol Chem. 2013;288:4462-74.

10. Purdy JE, Lana TP, Mann BJ, Petri WA. Upstream regulatory elements controlling expression of the Entamoeba histolytica lectin. Mol Biochem Parasitol. 1996:78:91-103.

11. Calixto-Galvez M, Romero-Diaz M, Garcia-Munoz A, Salas-Casas A, Pais-Morales J, Galvan IJ, Rodriguez MA. Identification of a polypeptide containing Tudor and staphyloccocal nuclease-like domains as the sequence-specific binding protein to the upstream regulatory element 1 of Entamoeba histolytica. Int J Parasitol. 2011:41:775-82.

12. Gilchrist CA, Holm CF, Hughes MA, Schaenman JM, Mann BJ, Petri WA. Identification and characterization of an Entamoeba histolytica upstream regulatory element 3 sequence-specific DNA-binding protein containing EFhand motifs. J Biol Chem. 2001:276:11838-43.

13. Schaenman JM, Gilchrist CA, Mann BJ, Petri WA. Identification of two Entamoeba histolytica sequence-specific URE4 enhancer-binding proteins with homology to the RNA-binding motif RRM. J Biol Chem. 2001;276:1602-9.

14. Marchat LA Gomez C, Perez DG, Paz F, Mendoza L, Orozco E. Two CCAAT/ enhancer binding protein sites are cis-activator elements of the Entamoeba histolytica EhPgp1 (mdr-like) gene expression. Cell Microbiol. 2002;4:725-37.

15. Ehrenkaufer GM, Hackney JA, Singh U. A developmentally regulated Myb domain protein regulates expression of a subset of stage-specific genes in Entamoeba histolytica. Cell Microbiol. 2009;11:898-910.

16. Meneses E, Cárdenas H, Zárate S, Brieba LG, Orozco E, López-Camarillo C, Azuara-Liceaga E. The R2R3 Myb protein family in Entamoeba histolytica. Gene. 2010;455:32-42

17. Manna D, Ehrenkaufer GM, Singh U. Regulation of gene expression in the protozoan parasite Entamoeba invadens: identification of core promoter elements and promoters with stage-specific expression patterns. Int J Parasitol. 2014;44:837-45

18. Luna-Arias JP, Hernandez-Rivas R, de Dios-Bravo G, Garcia J, Mendoza L, Orozco E. The TATA-box binding protein of Entamoeba histolytica: cloning of the gene and location of the protein by immunofluorescence and confocal microscopy. Microbiology. 1999;145:33-40. 
19. de Dios-Bravo G, Luna-Arias JP, Riverón AM, Olivares-Trejo JJ, LópezCamarillo C, Orozco E. Entamoeba histolytica TATA-box binding protein binds to different TATA variants in vitro. FEBS J. 2005;272:1354-66.

20. Iyer LM, Anantharaman V, Wolf MY, Aravind L. Comparative genomics of transcription factors and chromatin proteins in parasitic protists and other eukaryotes. Int J Parasitol. 2008;38:1-31.

21. Mendoza L, Orozco E, Rodriguez MA, Garcia-Rivera G, Sanchez T, Garcia E, Gariglio P. Ehp53, an Entamoeba histolytica protein, ancestor of the mammalian tumour suppressor p53. Microbiology. 2003;149:885-93.

22. Cruz OH, Marchat LA, Guillen N, Weber C, Rosas IL, Diaz-Chavez J, LopezCamarillo C. Multinucleation and polykaryon formation is promoted by the EhPC4 transcription factor in Entamoeba histolytica. Sci Rep. 2016;6:19611.

23. Crowley TE, Hoey T, Liu JK, Jan YN, Jan LY, Tjian R. A new factor related to TATA-binding protein has highly restricted expression patterns in Drosophila. Nature. 1993:361:557-61.

24. Rabenstein MD, Zhou S, Lis JT, Tijan R. TATA box-binding protein (TBP)related factor 2 (TRF2), a third member of the TBP family. Proc Natl Acad Sci USA. 1999;96:4791-6.

25. Kaltenbach L, Horner MA, Rothman JH, Mango SE, Barbara S. The TBP-like factor CeTLF is required to activate RNA polymerase II transcription during C. elegans embryogenesis. Mol Cell. 2000;6:705-13.

26. Hochheimer A, Zhou S, Zheng S, Holmes MC, Tjian R. TRF2 associates with DREF and directs promoter-selective gene expression in Drosophila. Nature. 2002:420:439-45.

27. Persengiev SP, Zhu X, Dixit BL, Maston GA, Kittler EL, Green MR. TRF3, a TATA-box-binding protein-related factor, is vertebrate-specific and widely expressed. Proc Natl Acad Sci USA. 2003;100:14887-91.

28. Guillebault D, Sasorith S, Derelle E, Wurtz JM, Lozano JC, Bingham S, Moreau $H$. A new class of transcription initiation factors, intermediate between TATA box-binding proteins (TBPs) and TBP-like factors (TLFs), is present in the marine unicellular organism, the dinoflagellate Crypthecodinium cohnii. J Biol Chem. 2002;277:40881-6.

29. Ruan JP, Arhin GK, Ullu E, Tschudi C. Functional characterization of a Trypanosoma brucei TATA-binding protein-related factor points to a universal regulator of transcription in trypanosomes. Mol Cell Biol. 2004;24:9610-8.

30. Castañon-Sanchez CA, Luna-Arias JP, de Dios-Bravo G, Herrera-Aguirre ME, Olivares-Trejo JJ, Orozco E, Hernandez JM. Entamoeba histolytica: a unicellular organism containing two active genes encoding for members of the TBP family. Protein Expr Purif. 2010;70:48-59.

31. Ali IK, Ehrenkaufer GM, Hackney JA, Singh U. Growth of the protozoan parasite Entamoeba histolytica in 5-azacytidine has limited effects on parasite gene expression. BMC Genomics. 2007;8:7.

32. Bracha R, Nuchamowitz Y, Mirelman D. Transcriptional silencing of an amoebapore gene in Entamoeba histolytica: molecular analysis and effect on pathogenicity. Euk Cell. 2003:2:295-305.

33. Orozco E, Guarneros G, Martinez-Palomo A, Sánchez T. Entamoeba histolytica. Phagocytosis as a virulence factor. J Exp Med. 1983;158:1511-21.

34. Coleman RA, Pugh BF. Evidence for functional binding and stable sliding of the TATA binding protein on nonspecific DNA. J Biol Chem. 1995;270:13850-9.

35. Shrimal S, Bhattacharya S, Bhattacharya A. Serum-dependent selective expression of EhTMKB1-9, a member of Entamoeba histolytica B1 family of transmembrane kinases. PLoS Pathog. 2010;6:e1000929.

36. Weber C, Guigon G, Bouchier C, Frangeul L, Moreira S, Sismeiro O, Guillén N. Stress by heat shock induces massive down regulation of genes and allows differential allelic expression of the gal/GalNAc lectin in Entamoeba histolytica. Euk Cell. 2006;5:871-5.

37. Weber C, Marchat LA, Guillén N, Lopez-Camarillo C. Effects of DNA damage induced by UV irradiation on gene expression in the protozoan parasite Entamoeba histolytica. Mol Biochem Parasitol. 2009;164:165-9.

38. López-Casamichana M, Orozco E, Marchat LA, López-Camarillo C. Transcriptional profile of the homologous recombination machinery and characterization of the EhRAD51 recombinase in response to DNA damage in Entamoeba histolytica. BMC Mol Biol. 2008:9:35

39. Charcas-Lopez MS, Garcia-Morales L, Pezet-Valdez M, Lopez-Camarillo C, Zamorano-Carillo A, Marchat LA. Expression of EhRAD54, EhRAD51, and EhBLM proteins during DNA repair by homologous recombination in Entamoeba histolytica. Parasite. 2014;21:7.

40. Betanzos A, Javier-Reyna R, García-Rivera G, Bañuelos C, González-Mariscal L, Schnoor M, Orozco E. The EhCPADH112 complex of Entamoeba histolytica interacts with tight junction proteins occludin and claudin-1 to produce epithelial damage. PLoS One. 2013;8:e65100.
41. Pais-Morales J, Betanzos A, García-Rivera G, Chávez-Munguía B, Shibayama $\mathrm{M}$, Orozco E. Resveratrol induces apoptosis-like death and prevents in vitro and in vivo virulence of Entamoeba histolytica. PLoS One. 2016;11:e0146287.

42. Livak KJ, Schmittgen TD. Analysis of relative gene expression data using real-time quantitative PCR and the 2(-Delta Delta C(T)) method. Methods. 2001;25:402-8.

43. Bruchhaus I, Leippe M, Lioutas C, Tannich E. Unusual gene organization in the protozoan parasite Entamoeba histolytica. DNA Cell Biol. 1993;12:925-33.

44. Bracha R, Nuchamowitz Y, Anbar M, Mirelman D. Transcriptional silencing of multiple genes in trophozoites of Entamoeba histolytica. PLoS Pathog. 2006;2:e48,

45. Avalos-Padilla Y, Betanzos A, Javier-Reyna R, García-Rivera G, ChávezMunguía B, Lagunes-Guillén A, Orozco E. EhVps32 is a vacuole-associated protein involved in pinocytosis and phagocytosis of Entamoeaba histolytica. PLoS Pathog. 2015;11:e1005079.

46. Hernandes-Alejandro M, Calixto-Gálvez M, López-Reyes I, Salas-Casas A, Cázares-Ápatiga J, Orozco E, Rodríguez MA. The small GTPase EhRabB of Entamoeba histolytica is differentially expressed during phagocytosis. Parasito Res. 2013;112:1631-40.

47. Singh U, Gilchrist CA, Schaenman JM, Rogers JB, Hockensmith JW, Mann BJ, Petri WA. Context-dependent roles of the Entamoeba histolytica Core promoter element GAAC in transcriptional activation and protein complex assembly. Mol Biochem Parasitol. 2002;120:107-12.

48. Grünberg S, Hahn S. Structural insights into transcription initiation by RNA polymerase II. Trends Biochem Sci. 2013;38:603-11.

49. Ravdin J, Guerrant RL. Role of adherence in cytopathogenic mechanisms of Entamoeba histolytica. Study with mammalian tissue culture cells and human erythrocytes J Clin Invest. 1981;68:1305-13.

50. Ralston KS, Solga MD, Mackey-Lawrence NM, Somlata BA, Petri WA. Trogocytosis by Entamoeba histolytica contributes to cell killing and tissue invasion. Nature. 2014;508:526-30.

51. Cheiki W, Kiyoshi K, Toru K, Hideki OA. General transcription initiation factor, human transcription factor IID, overexpressed in human lung and breast carcinoma and rapidly induced with serum stimulation. Cancer Res. 1992;52: 307-13.

52. Shimada M, Nakadai T, Tamura TA. TATA-binding protein-like protein (TLP/ TRF2/TLF) negatively regulates cell cycle progression and is required for the stress-mediated G (2) checkpoint. Mol Cell Biol. 2003;23:4107-20.

53. Saha A, Battacharya S, Bhattacharya A. Serum stress responsive gene EhsIncRNA of Entamoeba histolytica is a novel long noncoding RNA. Sci Rep. 2016;6:27476

54. de Nadal E, Ammerer G, Posas F. Controlling gene expression in response to stress. Nat Rev Genet. 2011;12:833-45.

55. Vichi $P$, Coin F, Renaud JP, Vermeulen W, Hoeijmakers JH, Moras D, Egly JM. Cisplatin- and UV-damaged DNA lure the basal transcription factor TFIID/ TBP. EMBO J. 1997:16:7444-56.

56. Vogel C, Marcotte EM. Insights into the regulation of protein abundance from proteomic and transcriptomic analyses. Nat Rev Genet. 2012:13:227-32.

57. Lavelle JP, Negrete HO, Poland PA, Kinlough CL, Meyers SD, Hughey RP. Low permeabilities of MDCK cell monolayers: a model barrier epithelium. Am J Phys. 1993;273:67-75.

58. Chelsea M, Petri WA. Regulation of virulence of Entamoeba histolytica. Annu Rev Microbiol. 2014:68:493-520.

59. Gilchrist CA, Houpt E, Trapaidze N, Fei Z, Crasta O, Asgharpour A, et al. Impact of intestinal colonization and invasion on the Entamoeba histolytica transcriptome. Mol Biochem Parasitol. 2006;147:163-76.

60. Weber C, Koutero M, Dillies MA, Varet H, Lopez-Camarillo C, Coppée JY, Guillén N. Extensive transcriptome analysis correlates the plasticity of Entamoeba histolytica pathogenesis to rapid phenotype changes depending on the environment. Sci Rep. 2016;6.

61. Baxt LA, Rastew E, Bracha R, Mirelman D, Singh U. Downregulation of an Entamoeba histolytica rhomboid protease reveals roles in regulating parasite adhesion and phagocytosis. Euk Cell. 2010;9:1283-93.

62. Mirelman D, Anbar M, Bracha R. Epigenetic transcriptional gene silencing in Entamoeba histolytica. IUBMB Life. 2008;60:598-604.

63. Romero-Díaz M, Gómez C, López-Reyes I, Martínez MB, Orozco E, Rodríguez MA. Structural and functional analysis of the Entamoeba histolytica EhrabB gene promoter. BMC Mol Biol. 2007:8(1):82. 